\title{
Dinophiliformia early neurogenesis suggests the evolution of conservative neural structures across the Annelida phylogenetic tree
}

\author{
Elizaveta Fofanova ${ }^{\text {Corresp., }}{ }^{,}$, Tatiana D Mayorova ${ }^{1,2}{ }^{,}$Elena Voronezhskaya ${ }^{1}$ \\ ${ }^{1}$ Department of Comparative and Developmental Physiology, Koltzov Institute of Developmental Biology RAS, Moscow, Russia \\ Laboratory of Neurobiology, National Institute of Neurological Disorders and Stroke, Bethesda, Maryland, USA \\ Corresponding Author: Elizaveta Fofanova \\ Email address: fofanova@idbras.ru
}

Despite the increasing data concerning the structure of the adult nervous system in various Lophotrochozoa groups, the early events during the neurogenesis of rare and unique groups need clarification. Annelida are a diverse clade of Lophotrochozoa, and their representatives demonstrate a variety of body plans, lifestyles, and life cycles. Comparative data about the early development are available for Errantia, Sedentaria, Sipuncula, and Palaeoannelida; however, our knowledge of Dinophiliformia is currently scarce. Representatives of Dinophiliformia are small interstitial worms combining unique morphological features of different Lophotrochozoan taxa and expressing paedomorphic traits. We describe in detail the early neurogenesis of two related species: Dimorphilus gyrociliatus and Dinophilus vorticoides, from the appearance of first nerve cells until the formation of an adult body plan. In both species, the first cells were detected at the anterior and posterior regions at the early trochophore stage and demonstrated positive reactions with pan-neuronal marker anti-acetylated tubulin only. Long fibers of early cells grow towards each other and form longitudinal bundles along which differentiating neurons later appear and send their processes. We propose that these early cells serve as pioneer neurons, forming a layout of the adult nervous system. The early anterior cell of $D$. vorticoides is transient and present during the short embryonic period, while early anterior and posterior cells in D. gyrociliatus are maintained throughout the whole lifespan of the species. During development, the growing processes of early cells form compact brain neuropile, paired ventral and lateral longitudinal bundles; unpaired medial longitudinal bundle; and commissures in the ventral hyposphere. Specific 5-HT- and FMRFaimmunopositive neurons differentiate adjacent to the ventral bundles and brain neuropile in the middle trochophore and late trochophore stages, i.e. after the main structures of the nervous system have already been established. Processes of 5-HT- and FMRFa-positive cells constitute a small proportion of the tubulin-immunopositive brain neuropile, ventral 
cords, and commissures in all developmental stages. No 5-HT- and FMRFa-positive cells similar to apical sensory cells of other Lophotrochozoa were detected. We conclude that: (i) like in Errantia and Sedentaria, Dinophiliformia neurogenesis starts from the peripheral cells, whose processes prefigure the forming adult nervous system, (ii) Dinophiliformia early cells are negative to 5-HT and FMRFa antibodies like Sedentaria pioneer cells. 


\section{Dinophiliformia early neurogenesis suggests the}

\section{2 evolution of conservative neural structures across the}

\section{Annelida phylogenetic tree}

4 Elizaveta Fofanova $^{1}$, Tatiana D. Mayorova ${ }^{1,2}$, Elena E. Voronezhskaya ${ }^{1}$

$5{ }^{1}$ Department of Comparative and Developmental Physiology, Koltzov Institute of

6 Developmental Biology RAS Moscow, Russia

$72^{2}$ Laboratory of Neurobiology, National Institute of Neurological Disorders and Stroke,

8 Bethesda, MD, USA

Corresponding Author:

Elizaveta Fofanova ${ }^{1}$

Vavilova street, 26, Moscow, 119334, Russia

Email address: fofanova@idbras.ru

\section{Abstract}

Despite the increasing data concerning the structure of the adult nervous system in various

Lophotrochozoa groups, the early events during the neurogenesis of rare and unique groups need clarification. Annelida are a diverse clade of Lophotrochozoa, and their representatives demonstrate a variety of body plans, lifestyles, and life cycles. Comparative data about the early development are available for Errantia, Sedentaria, Sipuncula and Palaeoannelida; however, our knowledge of Dinophiliformia is currently scarce. Representatives of Dinophiliformia are small interstitial worms combining unique morphological features of different Lophotrochozoan taxa and expressing paedomorphic traits. We describe in detail the early neurogenesis of two related species: Dimorphilus gyrociliatus and Dinophilus vorticoides, from the appearance of first nerve cells until the formation of an adult body plan. In both species, the first cells were detected at the anterior and posterior regions at the early trochophore stage and demonstrated positive reactions with pan-neuronal marker anti-acetylated tubulin only. Long fibers of early cells grow towards 
each other and form longitudinal bundles along which differentiating neurons later appear and send their processes. We propose that these early cells serve as pioneer neurons, forming a layout of the adult nervous system. The early anterior cell of $D$. vorticoides is transient and present during the short embryonic period, while early anterior and posterior cells in D. gyrociliatus are maintained throughout the whole lifespan of the species. During development, the growing processes of early cells form compact brain neuropile, paired ventral and lateral longitudinal bundles; unpaired medial longitudinal bundle; and commissures in the ventral hyposphere. Specific 5-HT- and FMRFa-immunopositive neurons differentiate adjacent to the ventral bundles and brain neuropile in the middle trochophore and late trochophore stages, i.e. after the main structures of the nervous system have already been established. Processes of 5-HT- and FMRFapositive cells constitute a small proportion of the tubulin-immunopositive brain neuropile, ventral cords, and commissures in all developmental stages. No 5-HT- and FMRFa-positive cells similar to apical sensory cells of other Lophotrochozoa were detected. We conclude that: (i) like in Errantia and Sedentaria, Dinophiliformia neurogenesis starts from the peripheral cells, whose processes prefigure the forming adult nervous system, (ii) Dinophiliformia early cells are negative to 5-HT and FMRFa antibodies like Sedentaria pioneer cells.

\section{Introduction}

Annelida are a diverse group of organisms with a variety of adult and larval body plans. Recent studies on neurogenesis have been focused on the species having free-swimming larvae in their life cycle: Sedentaria (C. teleta, M. fuliginosus); Errantia (P. dumerilii, P. maculata), Palaeoannelida (O. fusiformis), and Sipuncula (T. lageniformis). Detailed data concerning the neurogenesis of Chaetopteriformia, Amphinomida, and Dinophiliformia are absent. 
50 Our study is focused on early neurogenesis events in two species of the group Dinophiliformia, small interstitial worms combining unique morphological features of different Lophotrochozoan taxa and expressing paedomorphic traits. Dinophiliformia have segmented epithelial structures like other Annelida, although they have no chaeta; they possess parenchymatous organization and protonephridia similar to Platyhelminthes; and utilize gliding ciliary locomotion like meiobentic invertebrates and mollusks. Representatives of Dinophiliformia have direct development inside the egg capsule packed in cocoon and hatch as small worms; however, they possess specific ciliary structures (prototroch, ventral ciliary field) similar to free-swimming larvae (Beklemishev \& Kabata, 1969; Fofanova, Nezlin \& Voronezhskaya, 2014; Kerbl et al., 2016a). Moreover, the adult species resemble a trochophore larva in that they maintain prototroch, ciliary bands, ventral ciliary field, and protonephridia. Such characteristics allows to call the adult species of Dinophiliformia "neotenic trochophore" (Beklemishev \& Kabata, 1969). A later study of Dinophiliformia demonstrated paedomorphic traits in the adult nervous, muscular, and ciliary systems and supported the progenetic origin of Dinophiliformia (Windoffer $\&$ Westheide, 1988; Kerbl et al., 2016b). From one point of view, an interstitial environment (bottom marine environment or meiobenthic) may drive the paedomorphic evolution (Westheide, 1987), while another author suggests that interstitial organisms first appeared in evolution (Boaden, 1989). In both cases, the paedomorphic animals demonstrate simplified features that probably correspond to the early ontogenetic stages of an ancestral taxon. Moreover, the nervous system is one of the most conservative structures, the comparative analysis of which may infer the basal plan of the last common ancestor. That is why the structure of the Dinophiliformia nervous system has attracted the particular attention of researchers (Fofanova \& Voronezhskaya, 2012; Fofanova, Nezlin \& Voronezhskaya, 2014; Kerbl et al., 
73

74

$2016 b, a, 2017)$. However, the specification of the earliest differentiating cells expressing neuronal phenotype, the arrangement of their processes, and their fate in the course of development have not been addressed in these animals.

In a variety of Lophotrochozan species, the first neurons appear as early as the trochophore stage during development (Schmidt-Rhaesa, Harzsch \& Purschke, 2015). They are often located peripherally, and their emanating processes establish the network resembling the anlagen of the developing adult (definitive) nervous system. Therefore, in some species of mollusks and annelids, the early peripheral cells were speculated to serve the function of pioneer neurons (Croll \& Voronezhskaya, 1996; Voronezhskaya, Tyurin \& Nezlin, 2002; Voronezhskaya \& Elekes, 2003; Voronezhskaya \& Ivashkin, 2010; Nezlin \& Voronezhskaya, 2017; Yurchenko et al., 2019; Kumar et al., 2020). Pioneer neurons were first described in insect development and represent the cells whose processes navigate or pioneer the growing axons of later differentiating neurons (Bate, 1976; Klose \& Bentley, 1989).

Among Lophotrochozoa, the first neurons demonstrate a positive reaction to serotonin antibodies (5-HT-IR) in Annelida and Nemertea (Voronezhskaya, Tsitrin \& Nezlin, 2003; Fischer, Henrich \& Arendt, 2010; Chernyshev \& Magarlamov, 2010), while in mollusks they are positive to antiFMRFamide antibodies (FMRFa-IR) (Croll \& Voronezhskaya, 1996; Dickinson, Croll \& Voronezhskaya, 2000; Voronezhskaya, Tyurin \& Nezlin, 2002; Voronezhskaya, Tsitrin \& Nezlin, 2003; Dickinson \& Croll, 2003). These researches used a limited number of markers: acetylated alpha-tubulin, serotonin (5-HT), or FMRFamide (FMRFa) antibody to visualize the location and morphology of the earliest nerve cells. Until now, no specific markers were found for the early peripheral cells apart from the generally used immunolabelling (Conzelmann \& Jékely, 2012; Kumar et al., 2020). 
96

97

98

In addition to the early peripheral neurons, the other nerve elements were found in the trochophore stage, which belong to the apical or aboral sensory organ (ASO) of the larvae (Lacalli, 1981, 1994; Page \& Parries, 2000; Page, 2002; Page, 2002; Nielsen, 2004, 2005). The ASO is a part of the larval nervous system, located at the anterior pole of larvae, and comprises an apical ciliary tuft and receptor cells. In most representatives of Lophotrochozoa, the ASO consists of a specific number of flask-shaped receptor cells and displays serotonin-like immunoreactivity, and sometimes also FMRFamide-like immunoreactivity. The long basal processes of apical cells form a compact apical neuropile (Richter et al., 2010). While Dinophiliformia belongs to the lophotrochozoan Annelida, no ASO sign has been mentioned in their representatives.

Typically, in the course of development, the other elements of the larval nervous system (prototroch nerve, hyposphere nerve ring, etc.) and the anlagen of the adult nervous system (cerebral ganglia, ventral nerve cords, esophageal nerve circle, etc.) emerge soon after the appearance of the early peripheral and ASO neurons in most Lophotrochozoa (Nezlin, 2010; Hejnol \& Lowe, 2015; Nezlin \& Voronezhskaya, 2017; Yurchenko et al., 2019; Kumar et al., 2020).

Dinophiliformia includes three clades: Lobatocerebrum, Dinophilus, and Dimorphilus (MartínDurán et al., 2021; Worsaae et al., 2021). We chose Dinophilus vorticoides and Dimorphilus gyrociliatus to analyze the cells, which express positive immunoreaction against a pan-neural marker - acetylated $\alpha$-tubulin, in combination with immunoreaction to specific neuronal markers - 5-HT and FMRFamide, during these worms' development inside the egg capsule. We emphasize the time of appearance and location of the early peripheral cells, their fate, and the path of their processes; we analyze the relation between the early peripheral cells and the cells 
differentiating within the structures of the forming adult nervous system. We also searched for cells expressing the ASO phenotype in both normal and experimental conditions of increased 5HT synthesis. Our work presents a detailed description of the neural cells from the first appearance until the formation of the main structures of the adult nervous system.

\section{Materials and Methods}

\section{Culture maintaining}

The Dimorphilus gyrociliatus culture was obtained from the Mediterranean Sea, Napoli

Zoological Station (Italy). The animals were reared in small plastic aquaria with artificial

seawater (33\% salinity) at $21^{\circ} \mathrm{C}$ without aeration and fed with homogenized frozen nettle (Urtica sp.) leaves once a week. The worms lay cocoons on the substrate, the wall, or the base of the plate. During daily water change, we collected all the cocoons and put them into fresh vials. Thus, we obtained the dated developmental stages from cleavage to pre-hatch specimens. $D$. gyrociliatus cocoons contained 1-9 large (female) representatives and several small (dwarf male) representatives (Shearer, 1911; Mauri, Baraldi \& Simonini, 2003). In our work, we studied only females of D. gyrociliatus.

The work on Dinophilus vorticoides was conducted during the summer seasons at the White Sea, Pertsov White Sea Biological Station. The worms were collected in a subtidal zone during a low tide. We kept them in small tanks without aeration and six-well plates (for working with adhesive cell cultures) at $10{ }^{\circ} \mathrm{C}$ in filtered seawater and fed them with diatom Phaeodactylum $s p$. and Pseudinicshea delicatissima every day. Water was changed every time before feeding. The cocoons of $D$. vorticoides contained up to 30 representatives of the same size and both sexes.

Both Dinophiliformia species laid cocoons regularly. The cocoons were gently removed from the aquaria using a glass Pasteur pipette and placed into $30 \mathrm{~mm}$ Petri dishes with filtered seawater. The egg capsules were mechanically extracted from the cocoon and fertilization envelope with 
143 tiny needles for further immunocytochemical procedures. Dinophilus and Dimorphilus curl up

144 after the gastrula stage with the ventral side out during the further early-late trochophore stages.

145 Therefore, our images often show curved specimens, especially during the late stages.

146 Immunocytochemistry

147

D. gyrociliatus and D. vorticoides at various developmental stages were subjected to wholemount immunostaining using standard protocols and a range of markers. Each staining was carried out using at least 40-50 specimens of each developmental stage. Antibodies against the neurotransmitters serotonin (5-HT), FMRFamide (FMRFa), and acetylated alpha-tubulin, as a neuronal, pan-neuronal, and ciliary marker, were used together with confocal laser scanning microscopy. This set of antibodies has been successfully applied to investigate neurogenesis in a variety of invertebrate larvae. Antibodies against acetylated tubulin, the neuropeptide RFamide, and the monoamine transmitter serotonin label individual neurons and their processes, as well as tubulin-containing ciliary structures (Schmidt-Rhaesa, Harzsch \& Purschke, 2015). The specificity of the antibodies used in our study has previously been shown in various representatives of lophotrochozoan taxa including mollusks and annelids (Voronezhskaya \& Elekes, 1996; Dickinson, Croll \& Voronezhskaya, 2000; Voronezhskaya, Tsitrin \& Nezlin, 2003; Wanninger et al., 2005; Kristof, Wollesen \& Wanninger, 2008; Dyachuk \& Odintsova, 2009; Fischer, Henrich \& Arendt, 2010; Carrillo-Baltodano et al., 2019; Kumar et al., 2020; CarrilloBaltodano et al., 2021).

The representatives of Dinophilus vorticoides and Dimorphilus gyrociliatus at different developmental stages were fixed with 4\% paraformaldehyde (PFA) in phosphate-buffered saline (PBS, $0.01 \mathrm{mM}, \mathrm{pH}=7.4$ ) at $4{ }^{\circ} \mathrm{C}$ overnight. After fixation, the samples were washed three times at 15-minute intervals in PBS and incubated in a blocking solution (10\% normal goat serum and 
$1 \%$ bovine serum albumin in PBS) for 30 minutes at room temperature to eliminate non-specific binding. Then, preparations were incubated with primary antibodies for 3 days at $10^{\circ} \mathrm{C}$. We used anti-acetylated $\alpha$-tubulin antibodies (Sigma-Aldrich, USA; T-6793; mouse; monoclonal: clone 611B-1, ascites fluid) diluted 1:5000-1:10000 in PBS containing 0.1\% Triton X-100 (PBS-TX) to label stabilized microtubules in ciliary bands and neural elements. Specific neural cells were marked with anti-5HT and anti-FMRFamide antibodies (Immunostar, USA; 428002; rabbit; polyclonal; Product ID: 20080 and Immunostar, USA; 410002; rabbit; polyclonal; Product ID: 20091). Primary antibodies were washed three times for 10 minutes in PBS-TX solution. The primary antibodies were visualized with respective secondary goat-anti-rabbit and goat-antimouse antibodies conjugated with Alexa-488 (1:1000, Molecular Probes, USA; A-11008; goat; polyclonal) and Alexa-633 (1:1000, USA; A-21050; goat; polyclonal, Molecular Probes) diluted in PBS containing $0.1 \%$ Triton $\mathrm{X}-100$ overnight at $10^{\circ} \mathrm{C}$. Then, the preparations were washed with PBS three times for 10 minutes. Replacement of the primary antibodies with serum resulted in no staining. Reversal of the secondary antibodies (Alexa 633 and Alexa 488) gave the same staining pattern.

Cell nuclei were stained with DAPI $(0.25 \mu \mathrm{g} / \mathrm{ml})$ during the second washing. After washing in PBS, the specimens were mounted on glass slides in $70 \%$ glycerol for microscopic analysis and image acquisition. The elements demonstrating positive reactions were considered 5-HT and FMRFa immunoreactive (5-HT-IR and FMRFa-IR, respectively).

Confocal scanning microscopes TCS-SPE, TCS-SP5 (Leica Microsystems, Germany), and Nikon A1 (Nikon, Japan) equipped with the appropriate set of lasers, filters, and detectors were used for the detailed study of the various developmental stages. Stacks of optical sections taken with x63 objectives and $0.3-0.5 \mu \mathrm{m}$ intervals were processed with Leica LAS AF (Leica 
Microsystems, Germany) and Image J (NIH, USA) to obtain two-dimensional images. For each sample, the optimal number of stacks was selected to demonstrate the structures of interest. Optical sections were projected onto one image and then imported into the Adobe Photoshop $\mathrm{CC}$; the only parameters to be changed were brightness and contrast.

\section{Application of 5-HT and its biochemical precursor 5-HTP}

D. vorticoides at different developmental stages were incubated in $10^{-5} \mathrm{M}$ serotonin (5-HT) and 5-hydroxytryptophan (5-HTP) (Sigma-Aldrich, USA) for 3 hours. Fresh stock solutions in distilled water $\left(10^{-2} \mathrm{M}\right)$ were prepared immediately before each experiment. Negative controls for each experiment included treatment of animals with the final concentration of vehicle (distilled water) in filtered seawater. The experiments were performed at $10{ }^{\circ} \mathrm{C}$. After the incubation, the animals were washed with filtered seawater four times and were then fixed and stained with anti-5-HT and anti-tubulin antibodies as described above.

\section{Results}

\section{Relative staging}

Duration of development within the egg capsule differs in Dimorphilus

gyrociliatus and Dinophilus vorticoides. D. gyrociliatus hatch after 5 days, whereas $D$.

vorticoides hatch approximately 2 weeks after oviposition. External ciliary structures develop sequentially in the anterior-to-posterior direction in both species. Each stage has a specific ciliary pattern. Hence, we used external ciliation as a marker for the relative staging of $D$. vorticoides and $D$. gyrociliatus development.

The first cilia are visualized soon after stomodeum emergence when the gastrula stage can be distinguished in both species. These cilia appear in the episphere and constitute a prototroch (Fig.

$1 \mathrm{~A})$. The prototroch represents a circular ciliary band growing from above the stomodeum 
212 toward the dorsal side; since the left and right branches of the prototroch do not reach each other 213 on the dorsal side, the prototroch remains open there.

214 When the prototroch has been developed, the ventral ciliary field appears along the midline of 215 the ventral hyposphere beneath the mouth opening. The ventral ciliary field elongates in the anterior-to-posterior direction (Fig. 1 B) and becomes broader and bushier during further development; its cilia become longer.

When the ventral ciliary field has been established, transversal ciliary bands start to grow. One ciliary band, called the acrotroch, appears in the episphere above the prototroch. Like the prototroch, the acrotroch extends to the dorsal side and forms an incomplete ring around the episphere open on the dorsal side. Other ciliary bands emerge in the hyposphere, i.e. under the prototroch. Initially, they look like paired narrow ciliated strip-shaped regions on both sides of the ventral ciliary field. During further development, the ciliary bands become broader and longer as they extend to the dorsal side, where they fuse, forming ring-shaped ciliary bands around the hyposphere (Fig. $1 \mathrm{C}$ ). The number of the ciliary bands increases in the anterior-toposterior direction, reaching five by the moment of hatching (Fig. $1 \mathrm{C}$ ).

D. gyrociliatus and D. vorticoides are direct developers and hatch as the small young juvenile worm. Nevertheless, the stages inside the egg capsule are similar to those that pass the freeswimming larvae of other Lophotrochozoa. The characteristic ciliated structures such as prototroch and ventral ciliary field consequently appear in the course of both dinophlid species' development. Prototroch is the main characteristic of a typical trochophore according to Rouse and Nielsen's definition (Rouse, 1999, 2000). Based on the spatio-temporal ciliation pattern, we suggest the following postgastrulation developmental stages in $D$. vorticoides and $D$. gyrociliatus: early trochophore, middle trochophore and late trochophore (Fig. 1 A-C). 
235 Antibodies against acetylated $\alpha$-tubulin mark most neuronal cell bodies and their growing fibers.

236 Cross-staining with antibodies against acetylated $\alpha$-tubulin and the neurotransmitters serotonin

237 and FMRFamide provides a visualization of specific neurons and their processes. We provide a

238 description of the neuronal pattern in two Dinophiliformia species at each defined developmental

239 stage.

240 Neurogenesis during the early trochophore stage

241 In D. gyrociliatus and D. vorticoides, the first specific elements expressing a positive reaction to

242 anti-tubulin antibodies occurred during the early trochophore stage. In both species, the first cells 243 demonstrate neither 5-HT- nor FMRFa- immunoreactivity (Fig. 2), so the structures described at

244 this stage are only detected with anti-tubulin antibodies.

245 In D. gyrociliatus, the early trochophore stage passes relatively fast and lasts for just one day 246 (during the second day after oviposition). So, during this period, the visualized structures vary 247 significantly in different samples. Therefore, the sequence of neurogenesis was defined only after 248 the analysis of a large number of samples.

249 In D. gyrociliatus, the first cell appears at the periphery on the ventral side in the episphere, right 250 above the mouth (Fig. 2 A). This early anterior cell has two symmetrical basal processes which 251 grow laterally towards the prototroch (Fig. 2 A). Nuclear staining confirms that the positive 252 immunoreaction occurs in the body of the single solitary anterior cell but not in the neighboring 253 cells (Fig. 2 D).

254 By the end of the early trochophore stage, a pair of protonephridia develop in the episphere and 255 are clearly visible as tubulin-positive structures in addition to tubulin-positive fibers of early cells (Fig. 2 B, double arrowheads). The processes of the early anterior cell extend further in the 257 posterior direction, following the curvature of the developing specimen, and form the anlagen of 
258 the lateral and ventral bundles (Fig. 2 B). Growth cones are visible at the end of the left and right 259 ventral growing fibers. Some of the posterior processes grow towards each other, cross midline, 260 and form the first commissure (Fig. 2 B). In addition to the anterior cell, two symmetrically 261 located cells emerge on the left and right sides of the stomodeum (Fig. 2 B). Anteriorly oriented 262 branches of anterior and lateral cells bend towards each other and form the brain neuropile (Fig. 2632 B). Nuclear staining confirms that no additional cell bodies with positive immunoreaction 264 occur in the anterior region or laterally to the stomodeum (Fig. 2 E, F, F').

265 No 5-HT-IR and FMRFa-IR elements were detected by the end of the early trochophore stage 266 (Fig. 2 C).

267 In $D$. vorticoides, the early trochophore stage lasts 3 days (5-7 days after oviposition). Two 268 tubulin-positive cells are distinguished on the anterior and posterior poles simultaneously on the fifth day. The anterior cell is located ventrally, while the posterior cell occupies the dorsal side of 270 the hyposphere (Fig. 2 G). Basal processes of the anterior cell organize the anlage of the brain neuropile, while basal processes of the posterior cell do not go far from the cell body (Fig. 2 L).

272 Nuclear staining confirms that the positive signal occurs in the body of the anterior solitary cell 273 but not in the neighboring cells (Fig. $2 \mathrm{~J}$ ). By the end of the sixth day, the body of the anterior cell is no longer visible in the episphere (Fig. $2 \mathrm{H})$. Despite the disappearance of the positive reaction in the early anterior cell, the tubulinpositive fibers organize the compact brain neuropile, ventral bundles, and first and second 277 commissures (Fig. 2 H). Two cells are located symmetrically at the base of the first and second 278 commissures, and their processes join the ipsilateral ventral nerve bundle (Fig. 2 H, K). The posterior cell is not visible from the ventral side because it is displaced more dorsally following 280 the curved posterior region of the trochophore (Fig. 2 H). However, the tubulin-positive cell 
281 body and its two short lateral processes can be seen on the dorsal side. Nuclear staining confirms

282 that the positive signal occurs in the body of the anterior solitary cell but not in the neighboring

283 cells (Fig. 2 M). No 5-HT-IR and FMRFa-IR elements were detected (Fig. 2 I).

284 Neurogenesis during the middle trochophore stage

285 The first specific 5-HT-IR and FMRFa-IR cells are detected at the middle trochophore stage

286 in D. gyrociliatus. While only specific 5-HT-IR cells are detected in $D$. vorticoides. Note that the

287 5-HT-IR and FMRFa-IR processes from those cells constitute only a minor portion of the neural

288 structures visualized with a pan-neural marker acetylated $\alpha$-tubulin.

289 In D. gyrociliatus, tubulin-positive processes form a dense brain neuropile, paired ventral and

290 lateral bundles, and unpaired medial bundle; two commissures connect ventral bundles; solitary

291 thick processes run from the brain to the anterior region of the body (Fig. 3 A, B). The early

292 anterior cell remains in its position ventrally above the mouth. A single cell starts to express

293 tubulin-positive immunoreactivity at the dorsal posterior region of the body; thus, it is not visible

294 from the ventral side (Fig. 3 C, D). However, a single tubulin-positive body of posterior cell can

295 be distinguished among the tubulin-negative neighboring cells on the dorsal side (Fig. 3 F).

296 Neither anterior nor posterior cells demonstrate a positive reaction to serotonin.

297 The first positive 5-HT immunoreaction occur in three cells located symmetrically at the left and

298 right sides at the base of the first commissure (Fig. 3 B, C, D). Their long basal processes join

299 the first commissure and the ventral bundles going posteriorly and anteriorly to the brain

300 neuropile (Fig. 3 B, C, D). Nuclear staining confirms that each 5-HT-IR element represents a

301 solitary cell - thus, two groups of three cells are located at the base of the commissure (Fig. 3 D,

302 E, E').

Peer] reviewing PDF | (2021:03:58908:1:1:NEW 25 Aug 2021) 
D. vorticoides demonstrate a similar pattern of tubulin-positive structures as D. gyrociliatus with the exception of unpaired medial and paired lateral bundles while possessing more dense brain neuropile and one additional commissure (Fig. 3 G, L). Note the absence of tubulin-positive bodies in the anterior region, while thick processes extending from the neuropile are clearly visible (Fig. $3 \mathrm{~K}$ ). The posterior cell is present on the dorsal side and demonstrates no positive reaction with 5-HT (Fig. $3 \mathrm{~N}$ ).

The first 5-HT-IR cells are found as groups of two cells located at the base of first commissure and solitary cells located at the base of second commissure (Fig. 3 H, I, L). Nuclear staining confirms that the 5-HT-IR element at the base of the commissure represents a solitary cell (Fig. 3 M).

FMRFamide-positive elements occurred at the middle trochophore of D. gyrociliatus but not in $D$. vorticoides. Staining was confined to the body and processes of the early anterior cell, visible at the previous stage after anti-tubulin staining (Fig. 4 A). Specific staining allows us to visualize the processes of the early anterior cell among the tubulin-positive fibers. Numerous long processes extend basally from the cell body and run along with the paired ventral and lateral and unpaired medial bundles (Fig. 4 B). The lateral basal processes of the early anterior cell first enter the brain neuropile, then go along the prototroch to the middle line of the embryo, then turn in the posterior direction and follow the lateral bundles (Fig. 4 C). The short apical process runs toward the anterior surface (Fig. 4 D', E) and bears two long cilia (Fig. 4 E, F). Nuclear staining confirms that only early anterior cells express positive FMRFa reaction in the anterior region (Fig. 4 D, E; Fig. 5).

Neurogenesis during the late trochophore stage 
325 The specific 5-HT-IR and FMRFa-IR cells and their processes are detected at the late

326 trochophore stage in both D. gyrociliatus and D. vorticoides. Still, 5-HT-IR and FMRFa-IR

327 processes extending from those cells constitute only a minor proportion of the structures

328 visualized with a pan-neural marker acetylated $\alpha$-tubulin. Contrary to D. gyrociliatus FMRFa-IR

329 cells appear in $D$. vorticoides at late trochophore stage only.

In D. gyrociliatus, tubulin-positive processes become more prominent. They constitute a dense brain neuropile, paired ventral and lateral bundles, and unpaired medial bundle; two commissures connect ventral bundles; solitary thick processes run from the brain to the anterior region of the body (Fig. 6 A). The early anterior cell remains its position above the mouth. This cell bears a thin process running to the surface (Fig. 6 D). Nuclear staining confirms that the positive immunoreaction occurs in the body of the single solitary anterior cell but not in the neighboring cells (Fig. 6 D). A single posterior cell is present in the dorsal posterior region of the body (Fig. 6 F). Neither anterior nor posterior cells demonstrate a positive reaction to serotonin. The first positive 5-HT immunoreaction occurred in four cells located symmetrically at the left and right sides above the brain neuropile (Fig. $6 \mathrm{C}$ ). Their long basal processes join the brain neuropile and follow the ventral bundles (Fig. 6 B, C, D). Two groups of 5-HT-IR cells at the base of first commissure become more prominent. Their processes are visible in the paired ventral and unpaired medial bundles (Fig. 6 E). D. vorticoides demonstrates a similar pattern of tubulin-positive structures as D. gyrociliatus (Fig. $6 \mathrm{G}$ ). Note the absence of tubulin-positive bodies in the anterior region, while thick processes extending from the neuropile are clearly visible (Fig. $6 \mathrm{~J}$ ). The posterior cell is present on the dorsal side and demonstrates no positive reaction with 5-HT (Fig. 6 M). 
347 First 5-HT-IR cells found above the brain neuropile as two- four solitary cells ( Fig. $6 \mathrm{H}, \mathrm{I}$ ).

348 Nuclear staining confirms that the 5-HT-IR elements under the brain neuropile represent separate cells (Fig. $6 \mathrm{~K}$ ). 5-HT-IR elements at the level of commissures become more prominent as well as paired ventral and unpaired medial bundle (Fig. $6 \mathrm{H}, \mathrm{I}, \mathrm{K}$ ). Nuclear staining confirms that each 5-HT-IR element represents a solitary cell (Fig. $6 \mathrm{~K}, \mathrm{~L}$ ).

Solitary anterior FMRFamide-positive cell and their processes in D. gyrociliatus become more prominent by late trochophore stage (Fig. 7 A- C, F).The early anterior cell demonstrates FMRFa-IR and its multiple processes can be visible in main nerve structures: the brain neuropile, paired ventral and lateral and unpaired medial bundles (Fig. 7 B, C, F). The early anterior cell has short surface directed process (Fig. 7 D, E). Nuclear staining confirms that only early anterior cells express positive FMRFa reaction in the anterior region (Fig. 7 D, E). First FMRFa-IR elements appear at the late trochophore stage in $D$. vorticoides above the brain neuropile (Fig. 7 H, I). Nuclear staining confirms two solitary cells at the beginning of the late trochophore stage (Fig. $7 \mathrm{H}, \mathrm{J}$ ); an additional third cell is visible a bit later (Fig. $7 \mathrm{I}, \mathrm{K})$. One more solitary FMRFa-IR element appears at the level of intestine (Fig. 7 I). Nuclear staining confirms that this element represents a cell (Fig. 7 L). Note that intestine cell and the posterior cell are different, because the posterior cell does not express FMRFa at this stage (Fig. 7 M).

\section{The early anterior cell in D.gyrociliatus is present throughout the whole lifespan}

The anterior FMRFa-IR cell in D. gyrociliatus is detected through the early, middle, and late trochophore stages, juvenile, adult, and even senior stages (Fig. 8 A- G). It is an unpaired cell located medially in front of the brain (Fig. 8 D). This cell retains its position and morphology at all the aforementioned stages, including adult and senior (Fig. 8 F-F", G-G"). The cell body is 1.5 times bigger $(20 \pm 3 \mu \mathrm{m}$ in diameter, $\mathrm{n}=120)$ and can be easily distinguished among the other 
370 FMRFa-IR neighboring cells at senior stage (Fig. 8 G, G', G"). Prominent short thick apical

371 processes protrude from the body surface and bear cilia at the anterior tip (Fig. 8 A'-C', A"-C").

372 The thin basal FMRFa-IR processes of this early anterior cell are visible among the dense brain

373 neuropile (Fig. 8 C, C", D). Multiple basal processes can be followed in the prototroch nerve,

374 ventral and lateral bundles (Fig. 8 D).

375 It is worth repeating that in $D$. vorticoides, the anterior cell degenerates by the end of the early

376 trochophore stage and never expresses FMRFa-IR or 5-HT-IR.

377 Detailed structure of the Dinophiliformia apical region

378 We incubated D. vorticoides in 5-HT and 5-HTP to test whether the apical cells are able to uptake

379

380

381

382

383

384

385

386

387

388 serotonin or synthesize it from the immediate biochemical precursor. This feature is typical for cells belonging to the apical sensory organ (ASO) of most studied Lophotrochozoa.

In normal conditions, several flask-shaped cells are visible at the middle trochophore stage with anti-tubulin antibodies at the anterior region of D. vorticoides (Fig. 9 B). Upon short-term incubation (3 hours) in 5-HT $\left(10^{-5} \mathrm{M}\right)$ and 5-HTP $\left(10^{-5} \mathrm{M}\right)$, two of these tubulin-positive cells start to express positive 5-HT-IR (Fig. 9 B', B"). These paired cells are detected in the top anterior region, and the long basal process joins the brain neuropile (Fig. 9 B', B"). This experiment indicates the ability of certain apical cells to uptake exogenous serotonin as well as to convert 5-HTP to 5-HT. Note that cells with such a feature were detected at neither the early trochophore stage (Fig. 9 A, A', A") nor later in the course of ontogenesis: late trochophore (Fig. 9 C, C', C"), in pre-hatching (Fig. 9 D-D"), juvenile (Fig. 9 E-E"), and adults (Fig. 9 F-F"), while distinct 5-HT-IR occurred within cell bodies adjacent to the brain neuropile (Fig. 9 C-C') as well as within the brain neuropile and in the main neuronal bundles (Fig. 9 C-F, C'-F') 
392 Numerous epithelial cells with short sensory processes become 5-HT-IR in free-living pre-

393 hatching, juvenile and adult D. vorticoides after short-term incubation in 5-HTP but not 5-HT

394 (Fig. 9 D", E", F"). Bunches of cilia are visible at the tip of anterior process in each cell (Fig. 9

395 F"). This experiment demonstrates the presence of decarboxylase aromatic amino acid enzyme

396 but not a serotonin transporter in some sensory epithelial cells.

\section{Discussion}

398 We provide a detailed analysis of the early neuronal development of $D$. gyrociliatus and $D$.

399

400

401

402

403

404

405

406

407

408

409

410

411

412

413 vorticoides. We define three stages of embryonic development in both species and describe their ciliary and nervous structures landmarks (Fig. 10-14).

Since the duration of the embryonic period is different in D. gyrociliatus and D. vorticoides, we needed to validate the method, allowing to match their developmental stages. We found out that the pattern of differentiation of external ciliary structures is the same in both species: the prototroch appears first, followed by the ventral ciliary field and then by ciliary bands. Thus, these ciliary structures (along with an absolute timescale) can be used as temporal landmarks to compare developmental stages in two Dinophiliformia species with different durations of time they spend inside the egg. An external ciliation pattern was successfully used to define a particular developmental stage in other annelids (Bergter, Brubacher \& Paululat, 2008). Although Dinophiliformia develop directly, their early developmental stages are comparable with free-swimming larvae: early, middle and late trochophores. The trochophore is characterized by the presence of the prototroch, a preoral ciliary band (Rouse, 1999, 2000). Dinophiliformia retain this structure throughout their life as a paedomorphic trait (Kerbl et al., 2017). A recent analysis of gene expression confirmed the homology of the prototroch in 
414 indirect-developing annelids (Kempf, Page \& Pires, 1997; Kerbl et al., 2016b) and the

415 prototroch of adult D. gyrociliatus (Kerbl et al., 2017).

416 Comparative analysis of Dinophiliformia early neurogenesis

417 The early neurogenesis in many different lophotrochozoans has been thoroughly studied during

418

419

420

421

422

423

424

425

426

427

428

429

430

431

432

433

434

435

the last few decades in order to understand the differentiation, evolution, and physiology of the nervous system in these animals. A considerable amount of this research was performed using a simple and reliable method of the visualization of nervous structures: immunostaining with antibodies to ubiquitously present neuronal markers: acetylated tubulin (pan-neural marker), serotonin (5-HT), and a neuropeptide FMRFamide (Croll \& Voronezhskaya, 1995, 1996;

Conzelmann \& Jékely, 2012). We used the same approach in our work in order to gain a picture comparable to other studies.

Dinophiliformia is a sister to Pleistoannelida, uniting Sedentaria and Errantia (Martín-Durán et al., 2021). We further discuss the early events in the neurogenesis of Dinophiliformia and compare them to other lophotrochozoan animals within and beyond this clade.

The neurogenesis in both Dinophiliformia begins with the differentiation of two peripheral cells, one anterior and one posterior, emanating from their processes toward each other. This type of localization of the first cells expressing neuronal characters was registered in other annelids from Sedentaria (Kumar et al., 2020) and Errantia (Voronezhskaya, Tsitrin \& Nezlin, 2003; Starunov, Voronezhskaya \& Nezlin, 2017). Some other representatives of Sedentaria, however, lack a posterior cell (Brinkmann \& Wanninger, 2009; Meyer \& Seaver, 2009; Meyer et al., 2015; Carrillo-Baltodano \& Meyer, 2017), suggesting that the number and localization as well as transmitter content of the first cells in annelids can vary. 
436 The processes of the early anterior and posterior cells in both Dinophiliformia run in the area of 437 the prospective central nervous structures and create its general layout: brain neuropile, paired

438 ventral and lateral and unpaired medial longitudinal nerve bundles and several ventral

439 commissures. Nascent neural cells differentiate along the way of these processes. Such a

440

441

442

443

444

445

446

447

448

449

450

451

452

scenario of neural development, when neurogenesis starts from two or more peripheral neurons

located on the opposite poles of the larva, was considered ancestral for Pleistoannelida (Kumar et al., 2020). Our data on Dinophiliformia support this point of view (Fig. 14) and push back the

presence of this type of neurogenesis to the common ancestor of Dinophiliformia and

Pleistoannelida. Actually, this pattern of neurogenesis was also registered in other groups, for example, in mollusks (Redl et al., 2014; Pavlicek, Schwaha \& Wanninger, 2018; Battonyai et al., 2018; Yurchenko et al., 2019), Nemertea (Hiebert \& Maslakova, 2015), and Platyhelminthes (Rawlinson, 2010). This suggests that it might be much more ancient unless it evolved independently in these groups.

The fact that the processes of the early anterior and posterior cells in Dinophiliformia demarcate the layout of the central nervous system may indicate that these cells pioneer the development of the nervous system, although further molecular support is required. Whether these cells are pioneer neurons or not, the fact that they lack 5HT/FMRFa immunoreactivity set Dinophiliformia apart from many other Lophotrochozoa from distant groups, where the first neurons to differentiate are either 5HT or FMRFa immunoreactive. Representatives of different annelid groups (Oweniidae, Sedentaria, Errantia) show immunoreactivity to 5HT or FMRFa or both in their early anterior and posterior cells (Nedved, 2010, McDougall et al., 2006, Starunov, Voronezhskaya \&Nezlin, 2017, Voronezhskaya, Tsitrin\&Nezlin, 2003). Non-annelid Lophotrochozoa (mollusks) demonstrate FMRFa immunoreactivity in the presumable pioneer 
459

460

461

462

463

464

465

466

467

neurons (Voronezhskaya et al., 1999; Dickinson, Croll \& Voronezhskaya, 2000). Aside from this, 5HT or FMRFa immunoreactivity was detected in the first neural cells, associated with different structures and functions, in nemerteans (Chernyshev \& Magarlamov, 2010; Von Döhren, 2016), flatworms (Rawlinson, 2010), mollusks (Dyachuk \& Odintsova, 2009; Pavlicek, Schwaha \& Wanninger, 2018; Battonyai et al., 2018; Yurchenko et al., 2019), phoronids (HaySchmidt, 1990), and brachiopods (Altenburger \& Wanninger, 2010). The ubiquitous presence of 5HT or FMRFa immunoreactive early neurons in Lophotrochozoa suggests that it is likely to be an ancestral state. However, there are a few exceptions: a sedentarian annelid M. fuliginosus (Kumar et al., 2020), and some mollusks (Redl et al., 2014) possess the early neuron with other (still unidentified) transmitter phenotypes. Certainly, the first neurons do not have 5HT and FMRFa immunoreactivity in these animals. Thus, the absence of 5HT and FMRFa immunoreactivity in the first neurons is not unique for the early stages of Dinophiliformia but is apparently rare for annelids as well as other lophotrochozoans, and may suggest a derived state of early neurogenesis. Further research is needed to identify signaling molecules expressing in the early cells of Dinophiliformia.

\section{The anterior cell in D. gyrociliatus is a particular case}

The first neurons of Lophotrochozoa, which could be either pioneer neurons or sensory cells of the apical organ or other cells with an unknown function, are known to be transient as they disappear by the end of larval development (Voronezhskaya \& Ivashkin, 2010; Nezlin \& Voronezhskaya, 2017). Although it was shown in D. vorticoides, the anterior and posterior early cells in D. gyrociliatus are retained throughout the whole life of the species. At the early stage, these cells are detected with anti-tubulin antibodies; later on, they begin to express FMRFa immunoreactivity. The early anterior cell of $D$. gyrociliatus has a short apical neurite and several 
482 cilia and thus can be considered a sensory cell. In addition, this cell sends long basal processes to 483 the brain neuropile, the prototroch circular nerve, and the ventral, medial, and lateral cords. It 484 does not seem to be homologous to the anterior cell of $D$. vorticoides, which does not have 485 FMRFa immunoreactivity and is not sensory since it has no surface extensions. The fact that the

486 487 488

early anterior and posterior cells of $D$. gyrociliatus are present throughout the entire lifespan may be interpreted as a paedomorphic trait in D. gyrociliatus, related to its progenetic origin (Kerbl et al., 2016a).

The FMRFa-immunoreactive cells with similar location and/or time of appearance have been registered in close relatives of Dinophiliformia, C. teleta (Sedentaria) (Meyer \& Seaver, 2009; Meyer et al., 2015; Carrillo-Baltodano \& Meyer, 2017), P. maculata (Errantia) (Voronezhskaya, Tsitrin \& Nezlin, 2003), and P. agassizii (Sipunculida) (Kristof, Wollesen \& Wanninger, 2008). It has not been registered in other annelids and other Lophotrochozoa groups. Although these FMRFa-immunoreactive cells are not the first to differentiate in the aforementioned species, it is plausible that they are homologous to FMRFa-immunoreactive cell in D. gyrociliatus. Therefore, this cell might be a synapomorphy of a clade Pleistoannelida +Dinophiliformia + Sipuncula (Fig. 14).

\section{Where is the apical organ?}

The apical organ is a conservative neural structure developing early during the neurogenesis of lophotrochozoan larvae. It is a group of sensory FMRFamide- or 5-HT-immunoreactive cells, located adjacent to cerebral commissure and transient in appearance. The apical organ is thought to have been present in the common ancestor of Lophotrochozoa (Nielsen, 2005; Wanninger, 2008; Marlow et al., 2014) or even the common ancestor of Cnidaria and Bilateria (Marlow et al., 2014), and thus represents a plesiomorphic state in these animals. Our study on 
505

506

507

508

509

510

511

512

513

514

515

516

517

518

519

520

521

522

523

524

525

526

527

Dinophiliformia revealed no cells which could be assigned to the apical organ by their expression of 5-HT or FMRFamide immunoreactivity. However, anti-tubulin antibodies revealed sensory flask-shaped cells in an anterior region of embryos of D. gyrociliatus and D. vorticoides. The pharmacological approach showed that two of these cells could uptake 5-HT and synthesize it from the precursor during the limited period of neurogenesis. This result indicates that these cells have the transient expression of enzymes necessary for serotonin synthesis and transporters using for 5-HT uptake, and could thus be a remnant of an ASO cells. Therefore, the apical organ of Dinophiliformia was either significantly reduced or switched to the use of other signaling molecules, for example, other than FMRFamide neuropeptides, a wide variety of which are highly expressed in the brain of adult Dinophiliformia (Kerbl et al., 2017) and present in the apical sensory cells of other annelids (Kerbl et al., 2017). Both scenarios could result from Dinophiliformia evolution, which included simplification, miniaturization, paedomorphosis, and switch to direct development (Westheide, 1987; Hanken \& Wake, 1993; Müller \& Westheide, 2002; Kerbl et al., 2016a,b).

Free-swimming annelid larvae usually have a prominent apical organ (Voronezhskaya, Tsitrin \& Nezlin, 2003; McDougall et al., 2006; Starunov, Voronezhskaya \& Nezlin, 2017; Kumar et al., 2020; Carrillo-Baltodano et al., 2021). However, it was suggested to be reduced in a sedentarian C. teleta (Meyer \& Seaver, 2009; Meyer et al., 2015; Carrillo-Baltodano \& Meyer, 2017). Given that the trochophores of another sedentarian (Kumar et al., 2020) and Errantia (Voronezhskaya, Tsitrin \& Nezlin, 2003; Starunov, Voronezhskaya \& Nezlin, 2017) do have the apical organ, we speculate that the reduction of the apical organ in C. teleta and Dinophiliformia represents independent evolutionary events.

\section{Conclusions}


528 We revealed that the development of the nervous system in Dinophiliformia starts from two

529 neural cells located at the opposite poles of the body and probably serve as pioneer neurons. This

530 pattern of early neurogenesis is comparable to that of most representatives of Pleistoannelida and

531 perhaps represents a synapomorphy of a clade Dinophiliformia + Pleistoannelida. However,

532 Dinophiliformia has a few distinctions from most Pleistoannelida and other Lophotrochozoa in

533 that their early anterior and posterior cells lack 5-HT or FMRFa immunoreactivity and the apical 534 organ is reduced or simplified. Although Dinophiliformia share these characteristics with a few representatives of Pleistoannelida, we hypothesize that they evolved independently during the paedomorphic evolution of this group. We suggest that FMRFa immunopositive anterior cell is a synapomorphy for a clade Pleistoannelida + Dinophiliformia + Sipuncula. The fact that $D$. gyrociliatus, unlike $D$. vorticoides, retains this neuron through the lifespan probably reflects an extreme degree of paedomorphosis of this species.

These data add to our knowledge of how variable the early development in Annelida and Spiralia could be and to what extent evolutionary changes might affect such a conservative process as early neurogenesis.

\section{Acknowledgements}

The research was done using the equipment of the Core Centrum of the Institute of

Developmental Biology RAS. Light microscopy study was conducted using equipment of the

Center of microscopy WSBS MSU. We thank the anonymous native speakers from the Flarus and MDPI agencies for the professional language proofreading. The work was conducted under IDB RAS GBRP \# 0088-2021-0020.

\section{References}

Altenburger A, Wanninger A. 2010. Neuromuscular development in Novocrania anomala: evidence for the presence of serotonin and a spiralian-like apical organ in lecithotrophic 
552

553

554

555

556

557

558

brachiopod larvae. Evolution \& Development 12:16-24. DOI: 10.1111/j.1525142X.2009.00387.x.

Battonyai I, Voronezhskaya EE, Obukhova A, Horváth R, Nezlin LP, Elekes K. 2018. Neuronal Development in the Larvae of the Invasive Biofouler Dreissena polymorpha (Mollusca: Bivalvia), with Special Attention to Sensory Elements and Swimming Behavior. The Biological Bulletin 234:192-206. DOI: 10.1086/698511.

Beklemishev VN, Kabata Z. 1969. Principles of comparative anatomy of invertebrates. Edinburgh: Oliver \& Boyd.

Bergter A, Brubacher JL, Paululat A. 2008. Muscle formation during embryogenesis of the polychaete Ophryotrocha diadema (Dorvilleidae) - new insights into annelid muscle patterns. Frontiers in Zoology 5:1. DOI: 10.1186/1742-9994-5-1.

Boaden PJS. 1989. Meiofauna and the origins of the Metazoa. Zoological Journal of the Linnean Society 96:217-227. DOI: 10.1111/j.1096-3642.1989.tb02257.x.

Brinkmann N, Wanninger A. 2009. Neurogenesis suggests independent evolution of opercula in serpulid polychaetes. BMC Evolutionary Biology 9:270. DOI: 10.1186/1471-2148-9-270.

Carrillo-Baltodano AM, Boyle MJ, Rice ME, Meyer NP. 2019. Developmental architecture of the nervous system in Themiste lageniformis (Sipuncula): New evidence from confocal laser scanning microscopy and gene expression. Journal of Morphology 280:1628-1650. DOI: $10.1002 /$ jmor.21054.

Carrillo-Baltodano AM, Meyer NP. 2017. Decoupling brain from nerve cord development in the annelid Capitella teleta: Insights into the evolution of nervous systems. Developmental Biology 431:134-144. DOI: 10.1016/j.ydbio.2017.09.022. 
574 Carrillo-Baltodano AM, Seudre O, Guynes K, Martín-Durán JM. 2021. Early embryogenesis and

575

576

577

578

579

580

581

582

583

584

585

586

587

588

589

590

591

592

593

594 organogenesis in the annelid Owenia fusiformis. EvoDevo 12:5. DOI: 10.1186/s13227021-00176-z.

Chernyshev AV, Magarlamov TYu. 2010. The first data on the nervous system of hoplonemertean larvae (Nemertea, Hoplonemertea). Doklady Biological Sciences 430:48-50. DOI: 10.1134/S0012496610010163.

Conzelmann M, Jékely G. 2012. Antibodies against conserved amidated neuropeptide epitopes enrich the comparative neurobiology toolbox. EvoDevo 3:23. DOI: 10.1186/2041-9139$3-23$.

Croll RP, Voronezhskaya EE. 1995. Early FMRFamide-like immunoreactive cells in gastropod neurogenesis. Acta Biologica Hungarica 46:295-303.

Croll RP, Voronezhskaya EE. 1996. Early Elements in Gastropod Neurogenesis. Developmental Biology 173:344-347. DOI: 10.1006/dbio.1996.0028.

Dickinson AJG, Croll RP. 2003. Development of the larval nervous system of the gastropod Ilyanassa obsoleta. The Journal of Comparative Neurology 466:197-218. DOI: 10.1002/cne. 10863 .

Dickinson A, Croll R, Voronezhskaya E. 2000. Development of embryonic cells containing serotonin, catecholamines, and FMRFamide-related peptides in Aplysia californica. The Biological Bulletin 199:305-315. DOI: 10.2307/1543187.

Von Döhren J. 2016. Development of the Nervous System of Carinina ochracea (Palaeonemertea, Nemertea). PLOS ONE 11:e0165649. DOI: 10.1371/journal.pone.0165649. 
595

596

597

598

599

600

601

602

603

604

605

606

607

608

Dyachuk V, Odintsova N. 2009. Development of the larval muscle system in the mussel Mytilus trossulus (Mollusca, Bivalvia): Myo-anatomy of bivalve larvae. Development, Growth \& Differentiation 51:69-79. DOI: 10.1111/j.1440-169X.2008.01081.x.

Fischer AH, Henrich T, Arendt D. 2010. The normal development of Platynereis dumerilii (Nereididae, Annelida). Frontiers in Zoology 7:31. DOI: 10.1186/1742-9994-7-31.

Fofanova EG, Nezlin LP, Voronezhskaya EE. 2014. Ciliary and nervous structures in juvenile females of the annelid Dinophilus gyrociliatus (O. Schmidt, 1848) (Annelida: Polychaeta). Russian Journal of Marine Biology 40:43-52. DOI: 10.1134/S1063074014010040.

Fofanova E, Voronezhskaya E. 2012. The structure of Archiannelid Dinophilus gyrociliatus ventral nerve cords. Acta Biologica Hungarica 63:88-90. DOI: 10.1556/ABiol.63.2012.Suppl.2.11.

Hanken J, Wake DB. 1993. Miniaturization of Body Size: Organismal Consequences and Evolutionary Significance. Annual Review of Ecology and Systematics 24:501-519. DOI: 10.1146/annurev.es.24.110193.002441.

Hay-Schmidt A. 1990. Distribution of catecholamine-containing, serotonin-like and neuropeptide FMRFamide-like immunoreactive neurons and processes in the nervous system of the actinotroch larva of Phoronis muelleri (Phoronida). Cell and Tissue Research 259:105-118. DOI: 10.1007/BF00571435.

Hejnol A, Lowe CJ. 2015. Embracing the comparative approach: how robust phylogenies and broader developmental sampling impacts the understanding of nervous system evolution. Philosophical Transactions of the Royal Society B: Biological Sciences 370:20150045. DOI: $10.1098 /$ rstb.2015.0045. 
618 Hiebert LS, Maslakova SA. 2015. Expression of Hox, Cdx, and Six3/6 genes in the

619

620

621

622

623

624

625

626

627

628

629

630

631

632

633

634

635

636

637

638 hoplonemertean Pantinonemertes californiensis offers insight into the evolution of maximally indirect development in the phylum Nemertea. EvoDevo 6:26. DOI: 10.1186/s13227-015-0021-7.

Kempf SC, Page LR, Pires A. 1997. Development of serotonin-like immunoreactivity in the embryos and larvae of nudibranch mollusks with emphasis on the structure and possible function of the apical sensory organ. The Journal of Comparative Neurology 386:507528. DOI: 10.1002/(sici)1096-9861(19970929)386:3<507::aid-cne12>3.0.co;2-7.

Kerbl A, Conzelmann M, Jékely G, Worsaae K. 2017. High diversity in neuropeptide immunoreactivity patterns among three closely related species of Dinophilidae (Annelida). The Journal of Comparative Neurology 525:3596-3635. DOI: $10.1002 /$ cne. 24289 .

Kerbl A, Fofanova EG, Mayorova TD, Voronezhskaya EE, Worsaae K. 2016a. Comparison of neuromuscular development in two dinophilid species (Annelida) suggests progenetic origin of Dinophilus gyrociliatus. Frontiers in Zoology 13:49. DOI: 10.1186/s12983-0160181-X.

Kerbl A, Martín-Durán JM, Worsaae K, Hejnol A. 2016b. Molecular regionalization in the compact brain of the meiofaunal annelid Dinophilus gyrociliatus (Dinophilidae). EvoDevo 7:20. DOI: 10.1186/s13227-016-0058-2.

Kristof A, Wollesen T, Wanninger A. 2008. Segmental Mode of Neural Patterning in Sipuncula. Current Biology 18:1129-1132. DOI: 10.1016/j.cub.2008.06.066.

Peer) reviewing PDF | (2021:03:58908:1:1:NEW 25 Aug 2021) 
639 Kumar S, Tumu SC, Helm C, Hausen H. 2020. The development of early pioneer neurons in the

640

641

642

643

644

645

646

647

648

649

650

651

652

653

654

655

656

657

658

659

660

661 annelid Malacoceros fuliginosus. BMC Evolutionary Biology 20:117. DOI: 10.1186/s12862-020-01680-x.

Marlow H, Tosches MA, Tomer R, Steinmetz PR, Lauri A, Larsson T, Arendt D. 2014. Larval body patterning and apical organs are conserved in animal evolution. BMC biology 12:7. DOI: $10.1186 / 1741-7007-12-7$.

Martín-Durán JM, Vellutini BC, Marlétaz F, Cetrangolo V, Cvetesic N, Thiel D, Henriet S, Grau-Bové X, Carrillo-Baltodano AM, Gu W, Kerbl A, Marquez Y, Bekkouche N, Chourrout D, Gómez-Skarmeta JL, Irimia M, Lenhard B, Worsaae K, Hejnol A. 2021. Conservative route to genome compaction in a miniature annelid. Nature Ecology \& Evolution 5:231-242. DOI: 10.1038/s41559-020-01327-6.

Mauri M, Baraldi E, Simonini R. 2003. Effects of zinc exposure on the polychaete Dinophilus gyrociliatus: a life-table response experiment. Aquatic Toxicology 65:93-100. DOI: 10.1016/S0166-445X(03)00109-7.

McDougall C, Chen W-C, Shimeld SM, Ferrier DEK. 2006. The development of the larval nervous system, musculature and ciliary bands of Pomatoceros lamarckii (Annelida): heterochrony in polychaetes. Frontiers in Zoology 3:16. DOI: 10.1186/1742-9994-3-16.

Meyer NP, Carrillo-Baltodano A, Moore RE, Seaver EC. 2015. Nervous system development in lecithotrophic larval and juvenile stages of the annelid Capitella teleta. Frontiers in Zoology 12:15. DOI: 10.1186/s12983-015-0108-y.

Meyer NP, Seaver EC. 2009. Neurogenesis in an annelid: characterization of brain neural precursors in the polychaete Capitella sp. I. Developmental Biology 335:237-252. DOI: 10.1016/j.ydbio.2009.06.017. 
662 663

664

665

666

667

668

669

670

671

672

673

674

675

676

677

678

679

680

681

682

683

684

Müller MCM, Westheide W. 2002. Comparative analysis of the nervous systems in presumptive progenetic dinophilid and dorvilleid polychaetes (Annelida) by immunohistochemistry and cLSM: Nervous systems in progenetic polychaetes. Acta Zoologica 83:33-48. DOI: 10.1046/j.1463-6395.2002.00096.x.

Nezlin LP. 2010. The golden age of comparative morphology: Laser scanning microscopy and neurogenesis in trochophore animals. Russian Journal of Developmental Biology 41:381390. DOI: $10.1134 / \mathrm{S} 1062360410060056$.

Nezlin LP, Voronezhskaya EE. 2017. Early peripheral sensory neurons in the development of trochozoan animals. Russian Journal of Developmental Biology 48:130-143. DOI: 10.1134/S1062360417020060.

Nielsen C. 2005. Larval and adult brains. Evolution \& Development 7:483-489. DOI: 10.1111/j.1525-142X.2005.05051.x.

Pavlicek A, Schwaha T, Wanninger A. 2018. Towards a ground pattern reconstruction of bivalve nervous systems: neurogenesis in the zebra mussel Dreissena polymorpha. Organisms, Diversity \& Evolution 18:101-114. DOI: 10.1007/s13127-017-0356-0.

Rawlinson KA. 2010. Embryonic and post-embryonic development of the polyclad flatworm Maritigrella crozieri; implications for the evolution of spiralian life history traits. Frontiers in Zoology 7:12. DOI: 10.1186/1742-9994-7-12.

Redl E, Scherholz M, Todt C, Wollesen T, Wanninger A. 2014. Development of the nervous system in Solenogastres (Mollusca) reveals putative ancestral spiralian features. EvoDevo 5:48. DOI: 10.1186/2041-9139-5-48.

Richter S, Loesel R, Purschke G, Schmidt-Rhaesa A, Scholtz G, Stach T, Vogt L, Wanninger A, Brenneis G, Döring C, Faller S, Fritsch M, Grobe P, Heuer CM, Kaul S, Møller OS, 
Müller CH, Rieger V, Rothe BH, Stegner ME, Harzsch S. 2010. Invertebrate

neurophylogeny: suggested terms and definitions for a neuroanatomical glossary.

Frontiers in Zoology 7:29. DOI: 10.1186/1742-9994-7-29.

Rouse GW. 1999. Trochophore concepts: ciliary bands and the evolution of larvae in spiralian Metazoa. Biological Journal of the Linnean Society 66:411-464. DOI: 10.1111/j.10958312.1999.tb01920.x.

Rouse GW. 2000. Bias? What bias? The evolution of downstream larval-feeding in animals. Zoologica Scripta 29:213-236. DOI: 10.1046/j.1463-6409.2000.00040.x.

Schmidt-Rhaesa A, Harzsch S, Purschke G. 2015. Structure and Evolution of Invertebrate Nervous Systems. Oxford University Press. DOI:

10.1093/acprof:oso/9780199682201.001.0001.

Shearer C. 1911. The Problem of Sex Determination in Dinophilus gyrociliatus. Journal of the Marine Biological Association of the United Kingdom 9:156-160. DOI: $10.1017 / \mathrm{S} 002531540007332 \mathrm{X}$.

Starunov VV, Voronezhskaya EE, Nezlin LP. 2017. Development of the nervous system in Platynereis dumerilii (Nereididae, Annelida). Frontiers in Zoology 14:27. DOI: 10.1186/s 12983-017-0211-3.

Voronezhskaya EE, Elekes K. 1996. Transient and sustained expression of FMRFamide-like immunoreactivity in the developing nervous system of Lymnaea stagnalis (Mollusca, Pulmonata). Cellular and Molecular Neurobiology 16:661-676. DOI: 10.1007/BF02151903. 
706 707

708

709

710

711

712

713

714

Voronezhskaya EE, Elekes K. 2003. Expression of FMRFamide gene encoded peptides by identified neurons in embryos and juveniles of the pulmonate snail Lymnaea stagnalis. Cell and Tissue Research 314:297-313. DOI: 10.1007/s00441-003-0800-7.

Voronezhskaya EE, Hiripi L, Elekes K, Croll RP. 1999. Development of catecholaminergic neurons in the pond snail, Lymnaea stagnalis: I. Embryonic development of dopaminecontaining neurons and dopamine-dependent behaviors. The Journal of Comparative Neurology 404:285-296. DOI: 10.1002/(sici)1096-9861(19990215)404:3<285::aidcne1>3.0.co;2-s.

Voronezhskaya E, Ivashkin E. 2010. Pioneer Neurons: A Basis or Limiting Factor of Lophotrochozoa Nervous System Diversity? Russian Journal of Developmental Biology 41:337-346. DOI: 10.1134/S1062360410060019.

Voronezhskaya EE, Tsitrin EB, Nezlin LP. 2003. Neuronal development in larval polychaete Phyllodoce maculata (Phyllodocidae). The Journal of Comparative Neurology 455:299309. DOI: $10.1002 / \mathrm{cne} .10488$.

Voronezhskaya EE, Tyurin SA, Nezlin LP. 2002. Neuronal development in larval chiton Ischnochiton hakodadensis (Mollusca: Polyplacophora). Journal of Comparative Neurology 444:25-38. DOI: https://doi.org/10.1002/cne.10130.

Wanninger A. 2008. Comparative Lophotrochozoan Neurogenesis and Larval Neuroanatomy: Recent Advances from Previously Neglected Taxa. Acta Biologica Hungarica 59:127136. DOI: 10.1556/ABiol.59.2008.Suppl.21.

Wanninger A, Koop D, Bromham L, Noonan E, Degnan BM. 2005. Nervous and muscle system development in Phascolion strombus (Sipuncula). Development Genes and Evolution 215:509-518. DOI: 10.1007/s00427-005-0012-0. 
729 Westheide W. 1987. Progenesis as a principle in meiofauna evolution. Journal of Natural $730 \quad$ History 21:843-854. DOI: 10.1080/00222938700770501.

731 Windoffer R, Westheide W. 1988. The nervous system of the male Dinophilus gyrociliatus

732 (Polychaeta, Dinophilidae): II. Electron microscopical reconstruction of nervous anatomy

733

734

735

736 Annelida. Diversity 13:77. DOI: 10.3390/d13020077.

737

738 Peripheral sensory neurons govern development of the nervous system in bivalve larvae. EvoDevo 10:22. DOI: 10.1186/s13227-019-0133-6.

740

741 


\section{Figure 1}

Relative staging and timing of Dinophiliformia. Anti-acetylated tubulin labelling.

We define three developmental stages in both $D$. gyrociliatus and $D$. vorticoides: early trochophore (A), middle trochophore (B), and late trochophore stages (C). The lower part of the figure demonstrates the developmental tempo of both species. (A) The early trochophore stage and a schematic representation of this stage. Prototroch is being developed. (B) The ventral ciliary field is being developed in the anterior-posterior direction. (C) Ciliary bands develop in the anterior-posterior direction. Abbreviations: $p t$-prototroch; vcf-ventral ciliary field; act-acrotroch. Scale bar - $30 \mu \mathrm{m}$. 


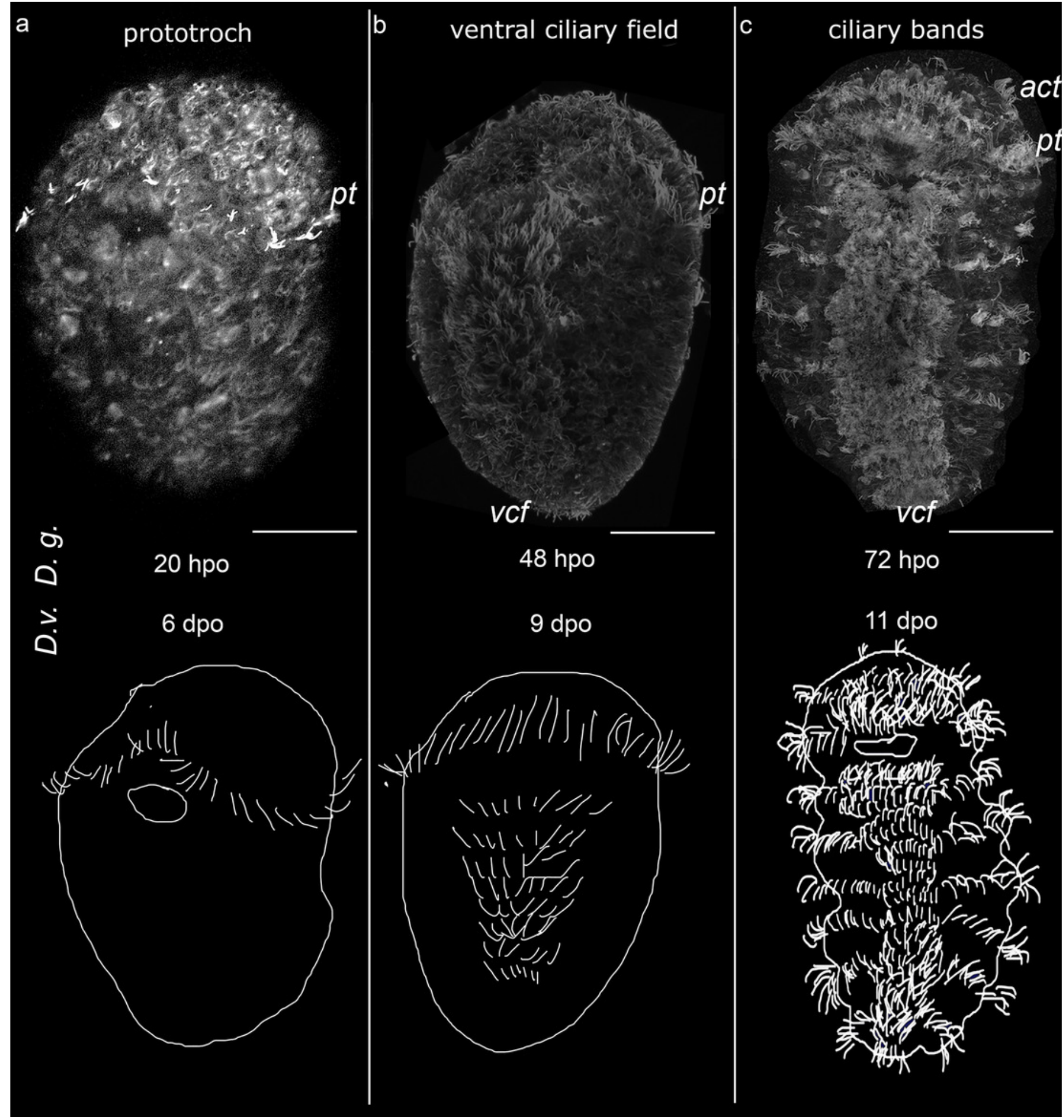




\section{Figure 2}

Development of acetylated tubulin-like (a-tub), FMRFamide-like, and 5-HT-like immunoreactivity during the early trochophore stage in $D$. gyrociliatus and $D$. vorticoides.

Yellow- acetylated tubulin immunoreactivity; magenta- 5-HT-like immunoreactivity; cyanFMRFa-like immunoreactivity; red - DAPI. Upper part- Dimorphilus gyrociliatus; Lower partDinophilus vorticoides. The early anterior (D. gyrocliatus, asterisk) and anterior+ posterior cells (D.vorticoides, asterisks) appear $(A, B, G, H)$. These cells do not demonstrate FMRFa-like or 5-HT-like immunoreactivity $(\mathrm{C}, \mathrm{I})$. Later during the early trochophore stage, the main structures of the nervous system are being developed $(B, H)$ : the neuropile (np), paired ventral bundles $(v b)$, and commissures $(c)$. Nuclear staining reveals a single nucleus in the early anterior cell in both $D$. gyrocilatus (D) and $D$. vorticoides (J). The early anterior cell in $D$. vorticoides is transient and is not detected after the head neuropile and ventral bundles had been developed $(\mathrm{H})$. At the same time, in D. gyrociliatus, it is still present (B). Nuclear staining reveals a single nucleus in the cell (E). In both $D$. gyrociliatus and D. vorticoides, other neurons appear at the cross of the ventral bundles and the first commissure $(B, H$, double arrows). Nuclear staining reveals a single nucleus in each cell in D. gyrociliatus ( $\left.F, F^{\prime}\right)$ and D. vorticoides (K). Dimorphilus gyrociliatus ventral bundles demonstrate growth cones at the posterior part of an embryo (arrows). In both D. gyrociliatus and D. vorticoides, ventral bundles also demonstrate growth cones ( $B, H$, arrows). The early posterior cell in $D$. vorticoides is present during the whole early trochophore stage on the dorsal side and has two processes (L). Nuclear staining reveals a single nucleus in the cell body (M). Abbreviations: $p t$ - prototroch, $n$-nucleus, $n p$-neuropile, $c$-commissure. Scale bars: A-C, F-H $25 \mu \mathrm{m} ; \mathrm{D}, \mathrm{E}, \mathrm{L}, \mathrm{M} 1 \mu \mathrm{m} ; \mathrm{F}, \mathrm{F}^{\prime}, \mathrm{J}-2,5 \mu \mathrm{m} ; \mathrm{K}-3,5 \mu \mathrm{m}$. 


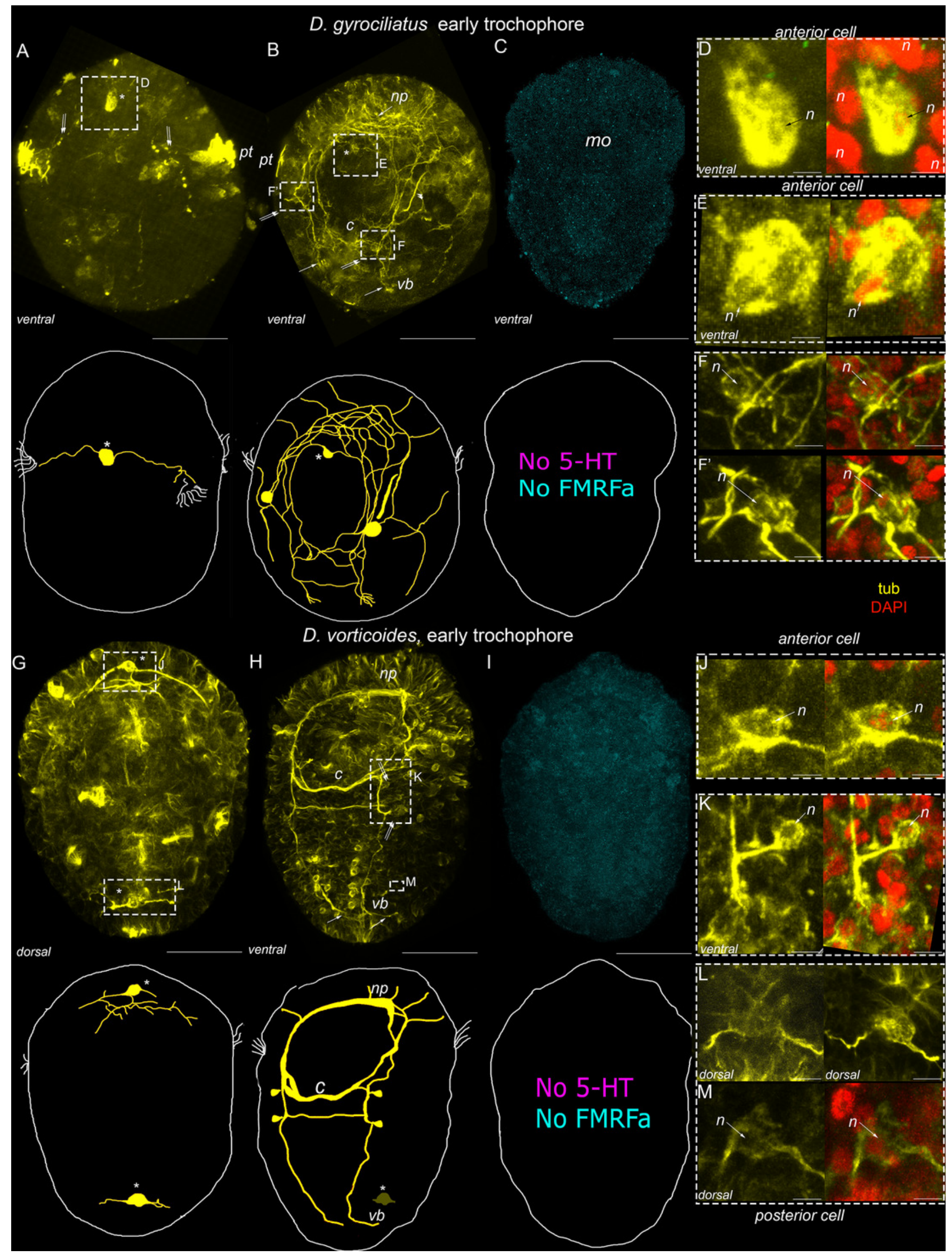




\section{Figure 3}

5-HT-like immunoreactivity during middle trochophore stage in $D$. gyrociliatus and $D$. vorticoides.

Yellow- acetylated tubulin immunoreactivity; magenta- 5-HT-like immunoreactivity; red-DAPI. Upper part-Dimorphilus gyrociliatus; Lower part- Dinophilus vorticoides. The main structures of the nervous system are developed in both $D$. gyrociliatus $(A)$ and $D$. vorticoides $(G)$. The neuropile contains more bundles (A, B, G, I, K). The first 5-HT-IR cells indicated with double arrows appear in both $D$. gyrociliatus $(\mathrm{B}, \mathrm{C}, \mathrm{D})$ and $D$. vorticoides $(\mathrm{H}, \mathrm{I}, \mathrm{L})$ at the commissure level. Nuclear staining reveals a single nucleus per cell body $\left(E, E^{\prime}, M\right)$. In $D$. gyrociliatus, the median nerve bundle and lateral bundle develop (C, D); additional commissures appear in the anterior-posterior direction ( $A, B, C)$. In D. gyrociliatus, the posterior cell ( $C, F$, asterisk) appears on the dorsal side, while in $D$. vorticoides it is still present on the dorsal side $(\mathrm{N})$. Its two processes meet ventral bundles on a dorsal side (F). The posterior cell has no 5-HT-IR. Abbreviations: $p t$ - prototroch, act- acrotroch, $m$ - median bundle, $v b$ - ventral bundle, Inlateral bundle, $n$ - nucleus, $c$ - commissure. Scale bars: A-C, G-I- $25 \mu \mathrm{m}$; D-7 $\mu \mathrm{m}, \mathrm{E}-3,5 \mu \mathrm{m}$; E', F- $2 \mu \mathrm{m} ; \mathrm{K}, \mathrm{L}-5 \mu \mathrm{m} ; \mathrm{M}-3,5 \mu \mathrm{m} ; \mathrm{N}-2 \mu \mathrm{m}$. 


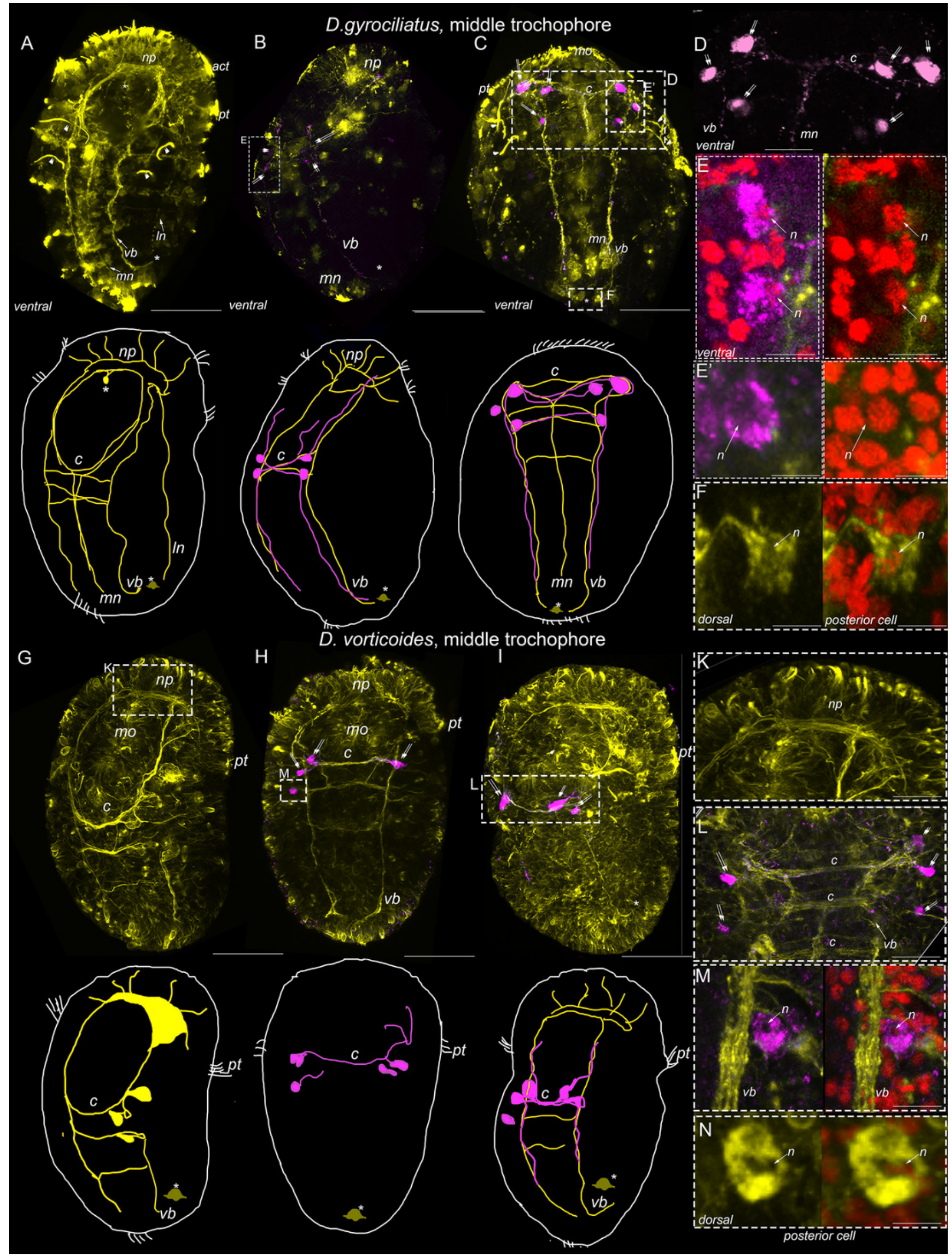




\section{Figure 4}

FMRFa-immunoreactivity during the middle trochophore stage in Dimorphilus gyrociliatus.

Red -DAPI, yellow- acetylated tubulin immunoreactivity; cyan- FMRFa-like immunoreactivity. Only D. gyrociliatus demonstrates FMRFa-IR during this stage. The main structures of the nervous system: the neuropile $(n p)$, ventral, medial nerve bundle $(m n)$, and lateral bundles (In) develop, and additional commissures appear in the anterior-posterior direction (A-C, E, F). The early anterior cell (asterisk) and its processes demonstrate FMRFa-IR (B, C, D, E). The lateral view shows that this cell has a process $(\mathrm{E})$ directed towards the surface and several cilia at the end of the process (D, D', E, F, double arrow). FMRFa-IR elements represent only a minor part of the whole nervous system. Scale bars: A - C- $30 \mu \mathrm{m} ; \mathrm{D}, \mathrm{D}^{\prime}-8 \mu \mathrm{m} ; \mathrm{E}, \mathrm{F}-5 \mu \mathrm{m}$. 


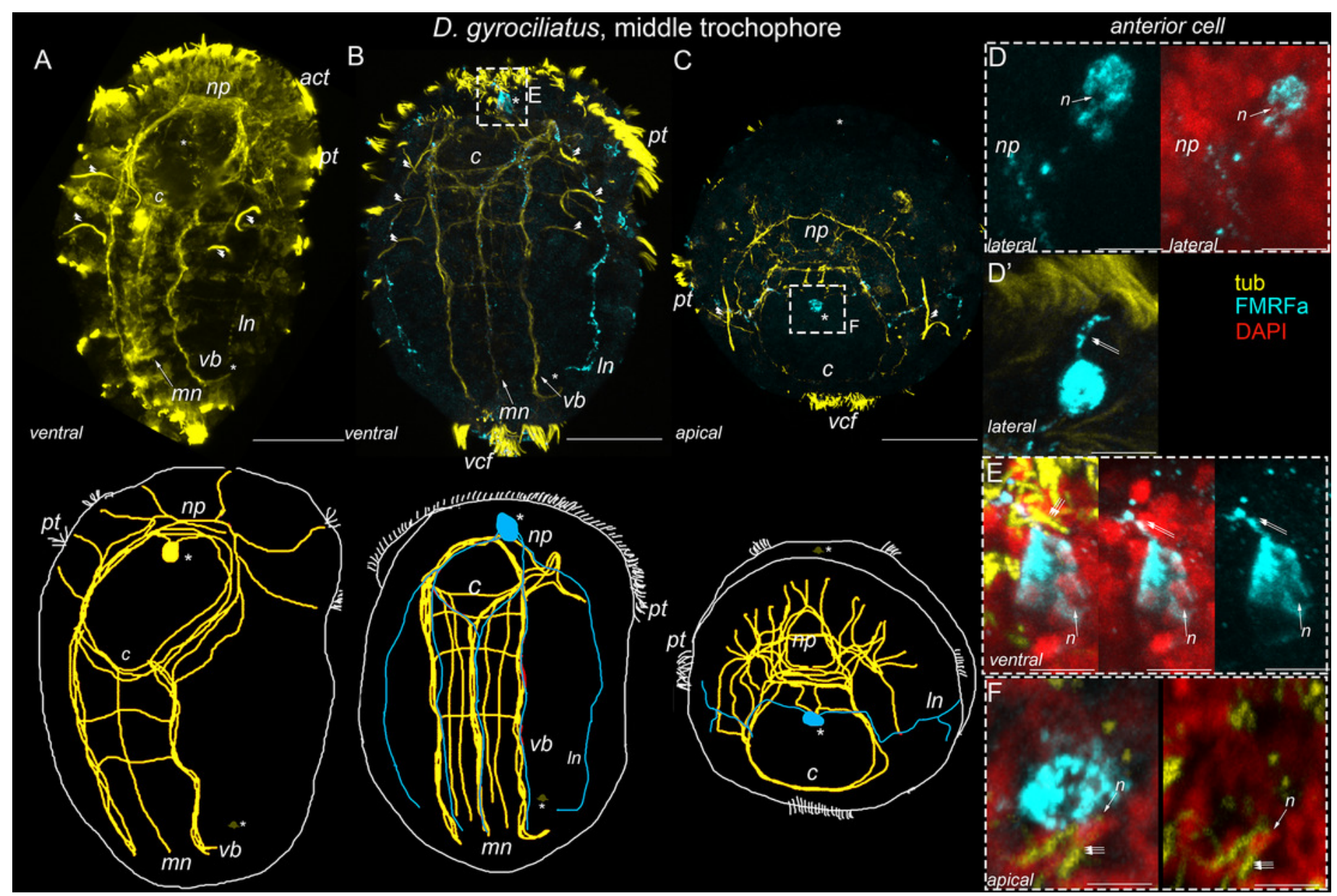




\section{Figure 5}

FMRFa-immunoreactive structures during the middle trochophore stage in $D$. gyrociliatus.

Yellow- acetylated tubulin immunoreactivity; cyan- FMRFa-like immunoreactivity; red- nuclear staining. The early anterior cell body is located at the periphery of the nervous system; it has surface cilia (A) just above the prototroch. The cell emanates several processes into the ventral bundles and prototroch nerve (B, C, D). Scale bar $25 \mu \mathrm{m}$. 


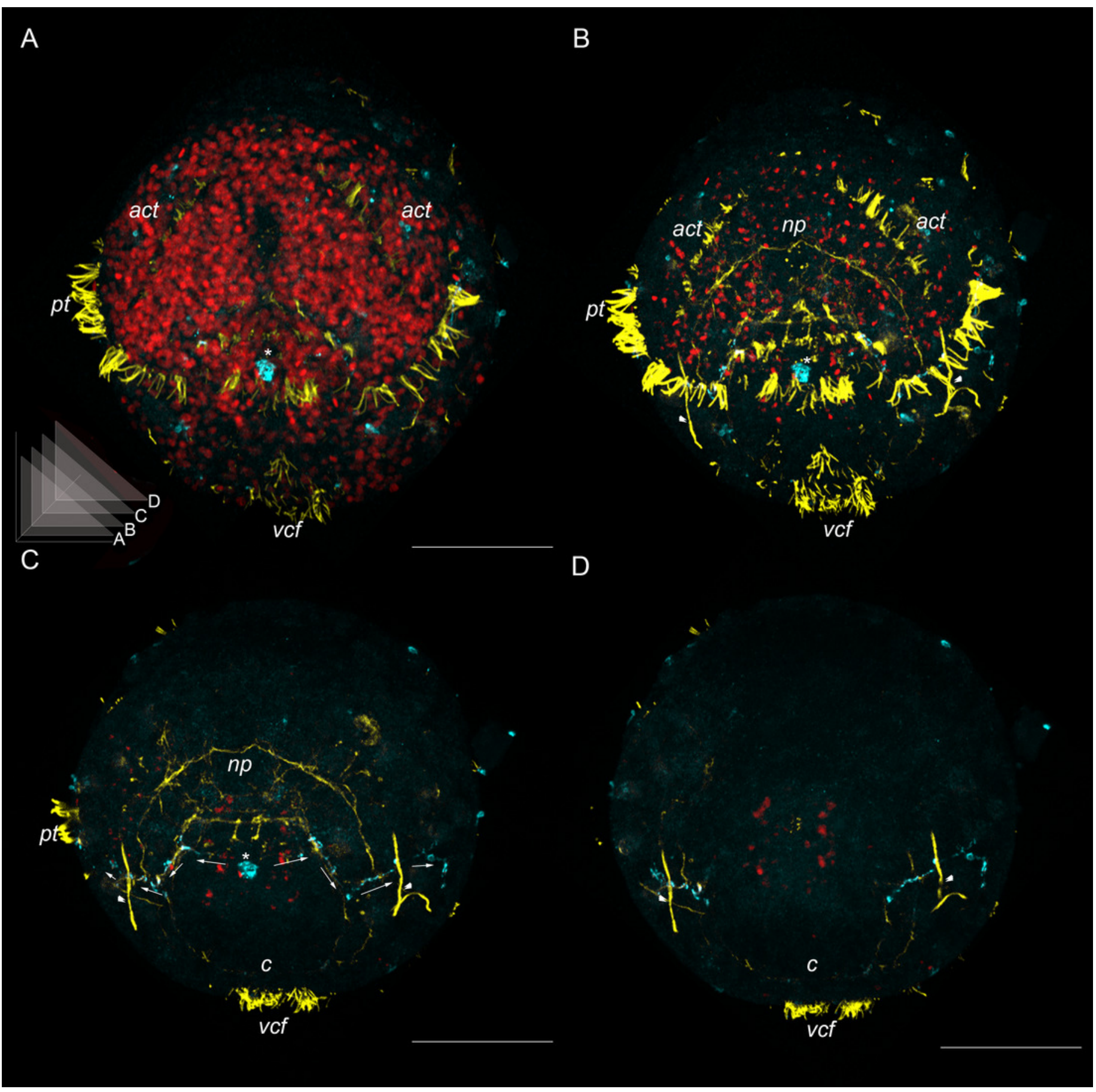




\section{Figure 6}

5-HT-immunoreactivity during the late trochophore stage.

Yellow- acetylated tubulin immunoreactivity; magenta- 5-HT- immunoreactivity, red- DAPI. Upper part-Dimorphilus gyrociliatus; Lower part-Dinophilus vorticoides. The main structures of the nervous system are well seen in both $D$. gyrociliatus and $D$. vorticoides (A-C, E, G-I). The neuropile contains more bundles (A-D, G- J) in both species. The early anterior cell in $D$. gyrociliatus bears a tiny surface process ( $D$, arrow); this cell is not 5 -HT-IR. $\ln D$. vorticoides the anterior cell is absent (J). Additional 5-HT-IR neurons appear in both $D$. gyrociliatus and $D$. vorticoides (double arrows) at the level of commissures (B, E, H, I, L). Nuclear staining allows identifying each cell (L). Four 5-HT-IR neurons appear under the neuropile (double arrows) in both $D$. gyrociliatus and $D$. vorticoides $(C, I)$. Nuclear staining allows counting each cell (K). The posterior cell is present in both $D$. gyrociliatus (F) and $D$. vorticoides (M). Scale bars: A C, G - I- $25 \mu \mathrm{m}$; D, E- $10 \mu \mathrm{m}$; F- $6 \mu \mathrm{m}$; K- $2 \mu \mathrm{m}$; J- $15 \mu \mathrm{m}$; L- $8 \mu \mathrm{m}$. 


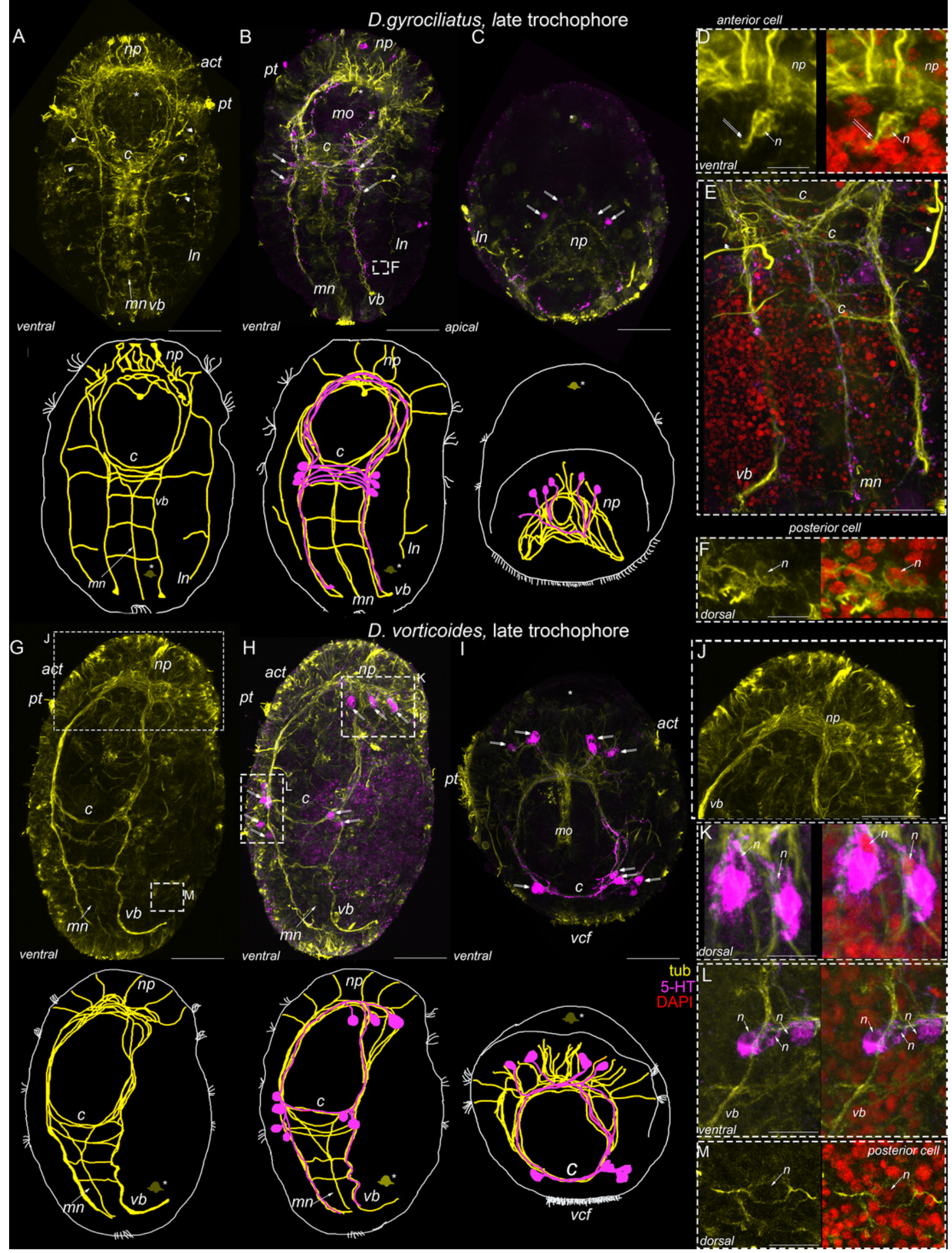




\section{Figure 7}

FMRFa-immunoreactivity during the late trochophore stage.

Yellow- acetylated tubulin immunoreactivity; cyan- FMRFa-like immunoreactivity, red- nuclear staining with DAPI. Upper part- Dimorphilus gyrociliatus; Lower part- Dinophilus vorticoides. In both species, the main nervous structures become more prominent and contain more bundles (A-C, F, G-I). In D. gyrociliatus, only the early anterior cell and its processes demonstrate FMRFa-IR. Close-ups demonstrate a lateral view of the early anterior cell with a round nuclear area and tiny process (arrow) (D, E). FMRFa-IR nervous structures represent a minor part of the whole nervous system (B, C, F). In D. vorticoides, two first FMRFa-IR cells appear on the dorsal side above the neuropile $(H)$. Short processes of these cells are incorporated into the neuropile. Later, other FMRFa-IR cells appear in the head region (I). The nuclear area and the nuclei are shown on close-ups (J, K). Additional FMRFa-IR cell appears along the intestine (I). This cell has a single process (L). The posterior cell is present (M). Scale bars: A-C, G-I $25 \mu \mathrm{m}$; D- E, J, L $5 \mu \mathrm{m}$; F- $8 \mu \mathrm{m}$; K- $5 \mu \mathrm{m}$; M- 2,5 $\mu \mathrm{m}$. 


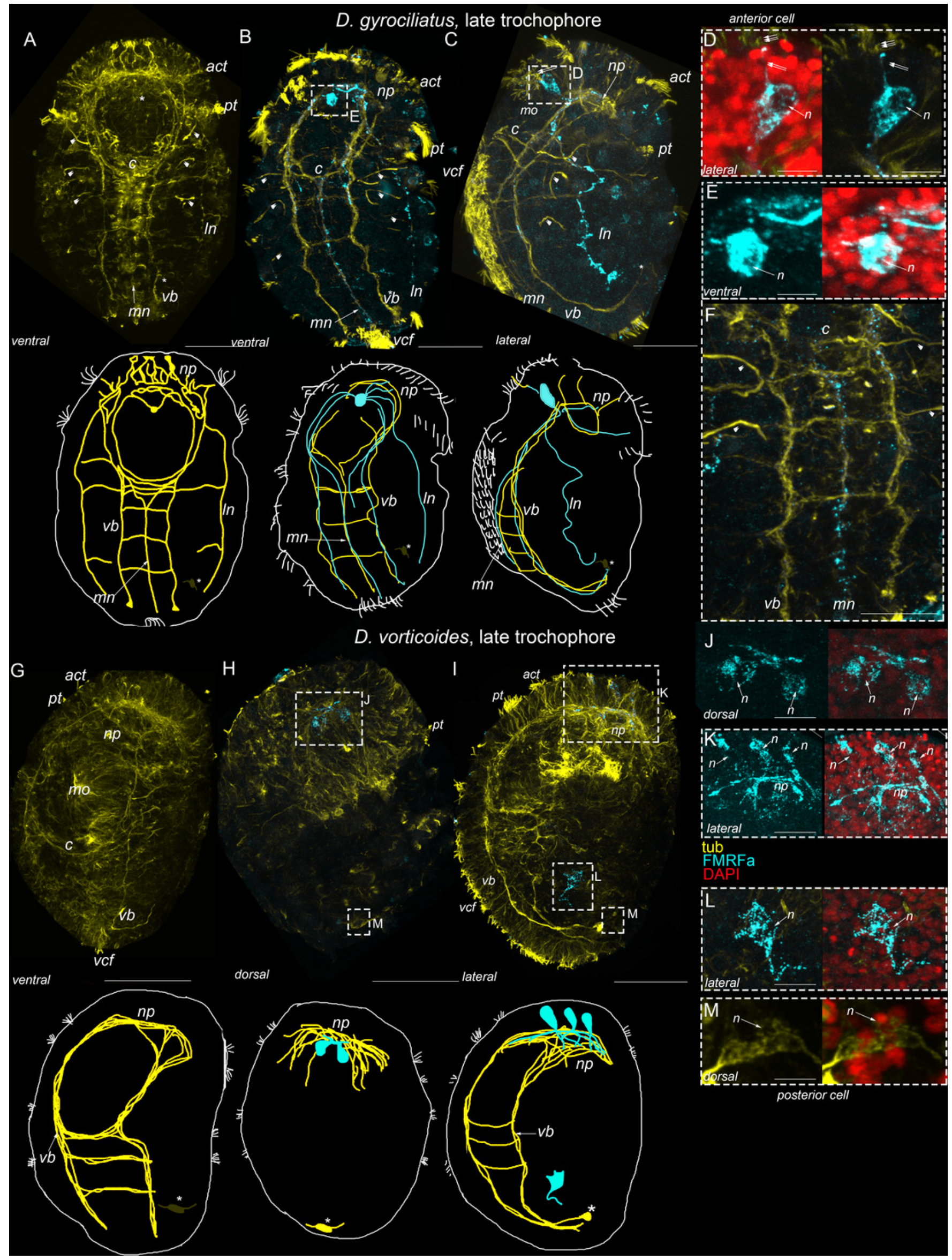




\section{Figure 8}

The ontogeny of the early anterior cell in $D$. gyrociliatus from the early trochophore stage to the senior specimen.

Red-acetylated tubulin immunoreactivity; cyan- FMRFa-like immunoreactivity. The early anterior cell is shown in frontal (A-G), apical ( $\left.A^{\prime}-G^{\prime}\right)$, and lateral (A"- $G^{\prime \prime}$ ) projections from the early trochophore to senior stages. During the early trochophore stage $(A)$, the cell appears above the prototroch and bears cilia (arrows) on its surface. It does not demonstrate FMRFaIR. During the middle trochophore stage, the early anterior cell becomes FMRFa-IR (B).

During late trochophore, juvenile, adult, and senior stages, the early anterior cell becomes more prominent and noticeable (C, D, F). The cell is not a part of the CNS as it is located separately from the neuropile (D). Even at the senior stage, this cell is visible $(G)$ and still bears cilia on its surface. Scale bars: A-C, F - G $5 \mu \mathrm{m}$; D- $40 \mu \mathrm{m}$. 


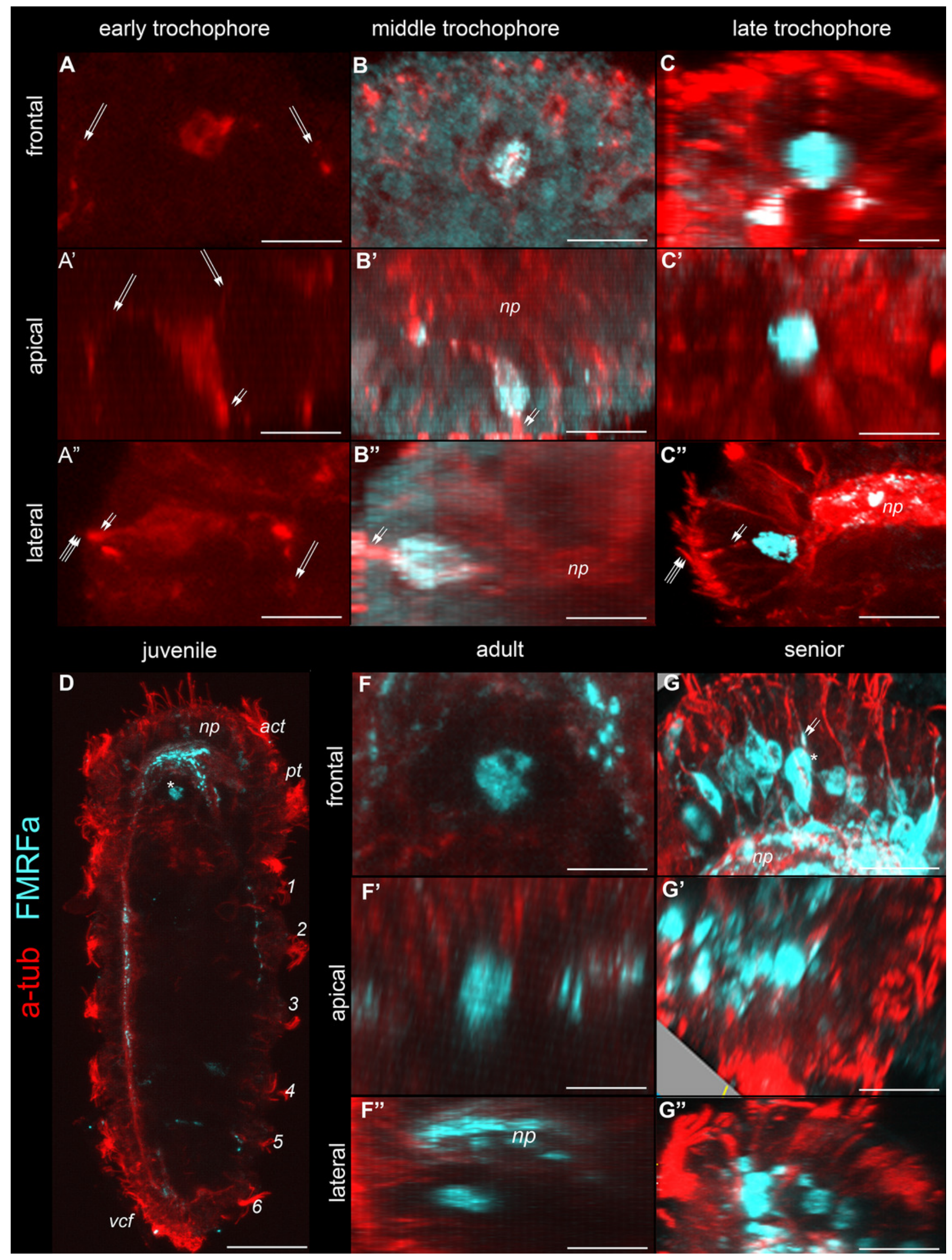




\section{Figure 9}

5-HT and 5-HTP incubation from the early trochophore to the adult stage of $D$. vorticoides.

Magenta - tubulin, green - 5-HT-like immunoreactivity. During the early trochophore stage, no $5 \mathrm{HT}$-IR elements are visualized in control (A), 5-HT (A'), and 5-HTP (A") treated animals. At the middle trochophore stage, two apical cells are visualized above the neuropile after 5-HT (B') and 5-HTP (B") treatment, while no 5HT-IR cells are visible in the control group (B). During the late trochophore stage, apical cells are detected neither in control (C) nor after 5HT ( $\left.C^{\prime}\right)$ and 5-HTP ( $\left.C^{\prime \prime}\right)$ treatment. No apical cells are visible in control, and 5-HT or 5-HTP treated worms at the pre-hatch (D-D"), juvenile (E-E"), and adult stages (F-F"). Scale bars 40 $\mu \mathrm{m}$. 


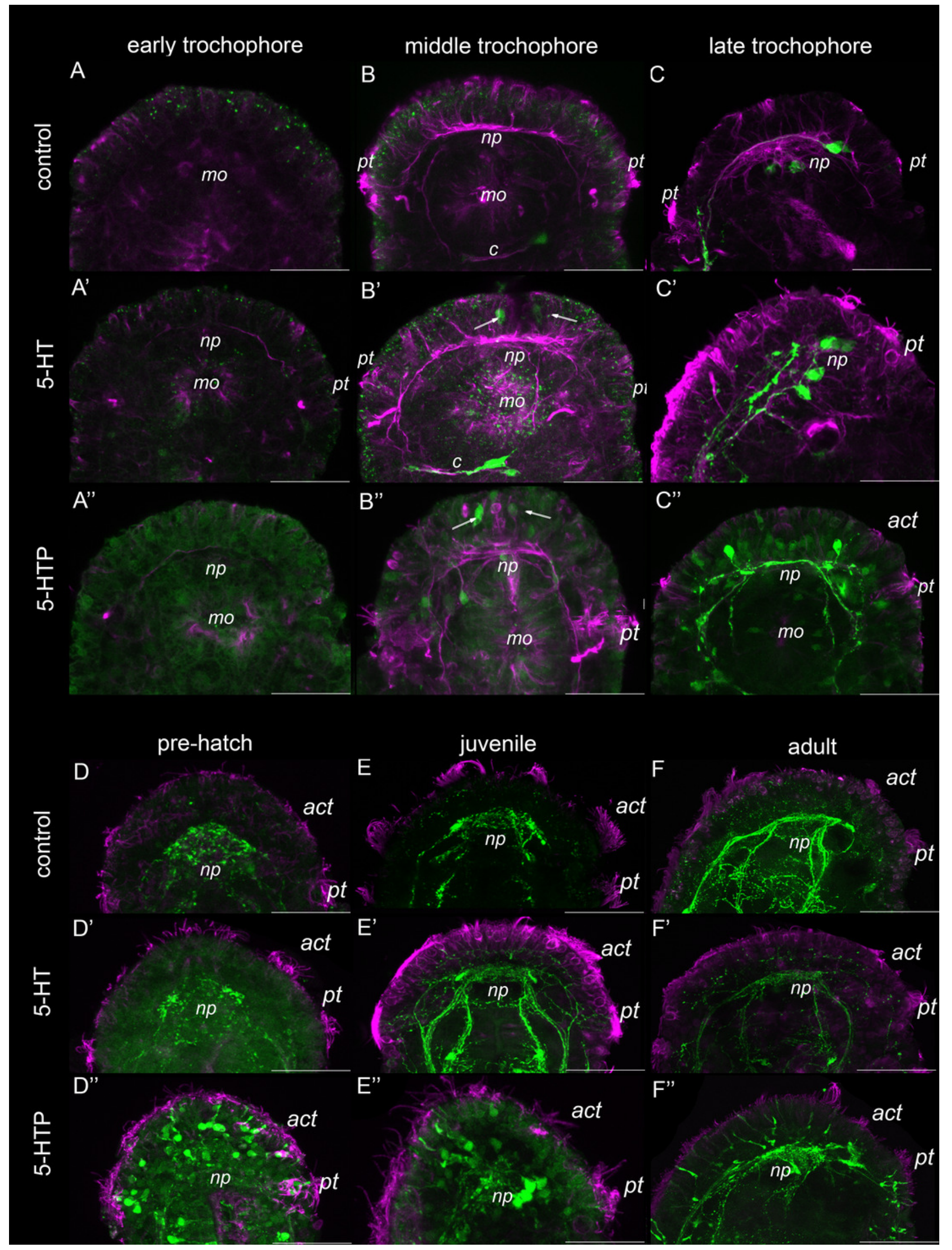




\section{Figure 10}

Summary diagram of the development of tubulin-immunoreactive neural structures in $D$. gyrociliatus and $D$. vorticoides.

The first nerve cells appear during the early trochophore stage in $D$. gyrociliatus and $D$. vorticoides. In $D$. gyrociliatus, it is the peripheral early anterior cell bearing surface cilia and located above the prototroch on the ventral side. This cell has multiple fibers on its basal part. In $D$. vorticoides, there are two early peripheral anterior and posterior cells, both of which are non-sensory. These cells have multiple fibers. In $D$. gyrociliatus, the early anterior cell is present during the middle and late trochophore stages. $\ln D$. vorticoides, the anterior cell is detectable only during the early trochophore stage. In both $D$. gyrociliatus and $D$. vorticoides, the nervous system develops from both poles of the body. The apical end is up. Relative dimensions are not to scale. 


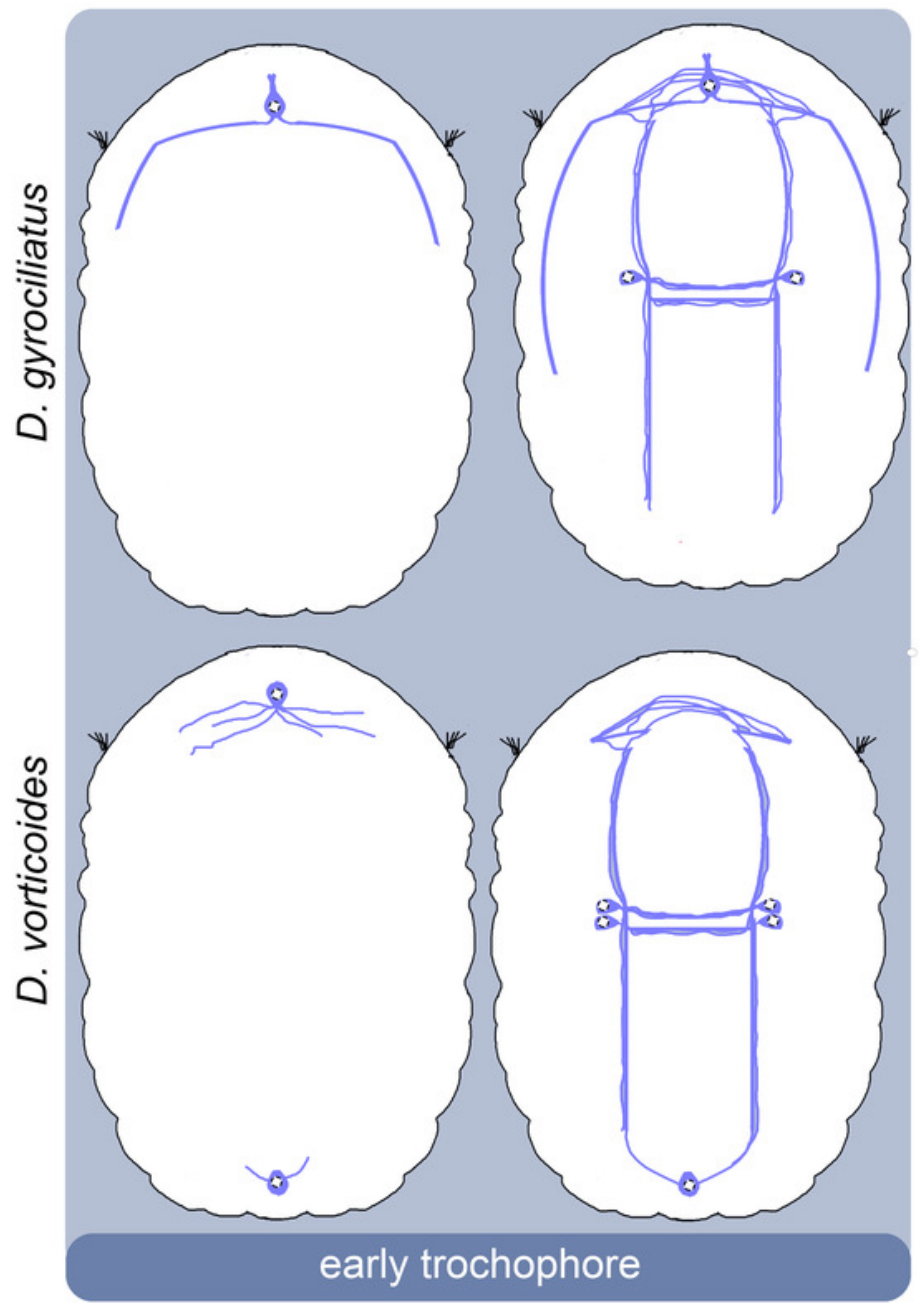

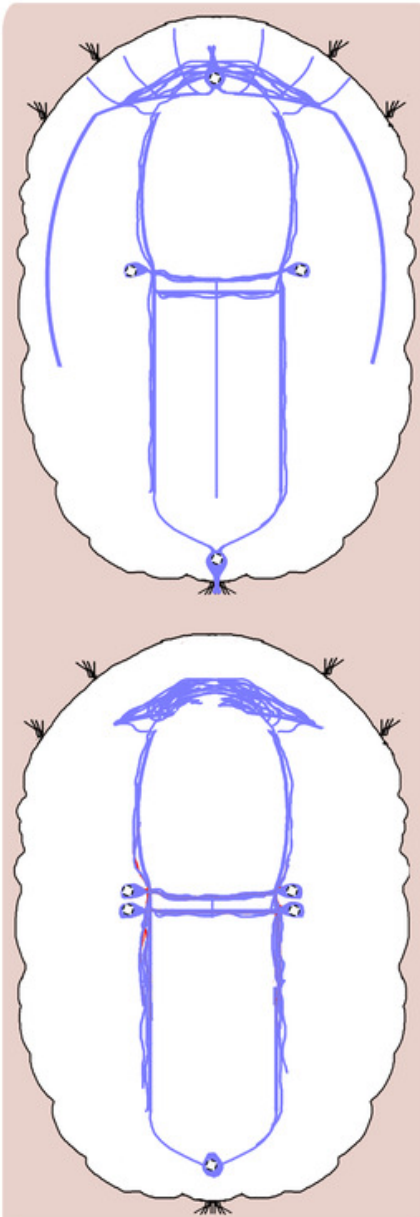

middle trochophore

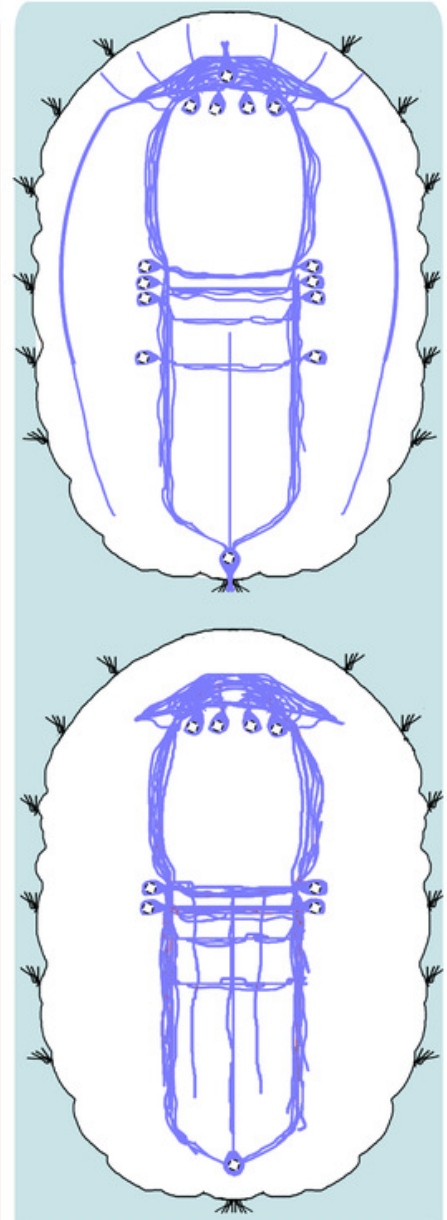

late trochophore 
Figure 11

Summary diagram of 5-HT-IR elements in D. gyrociliatus and D. vorticoides.

The first 5HT-IR cells appear at the middle trochophore stage in both species at the level of the first commissure. The processes of these cells join the main nerve structures- ventral bundles and the neuropile. Additional 5-HT-IR cells appear in the head region and ventral bundles at the late trochophore stage. The apical end is up. Relative dimensions are not to scale. Blue- tubulin; pink- 5-HT.
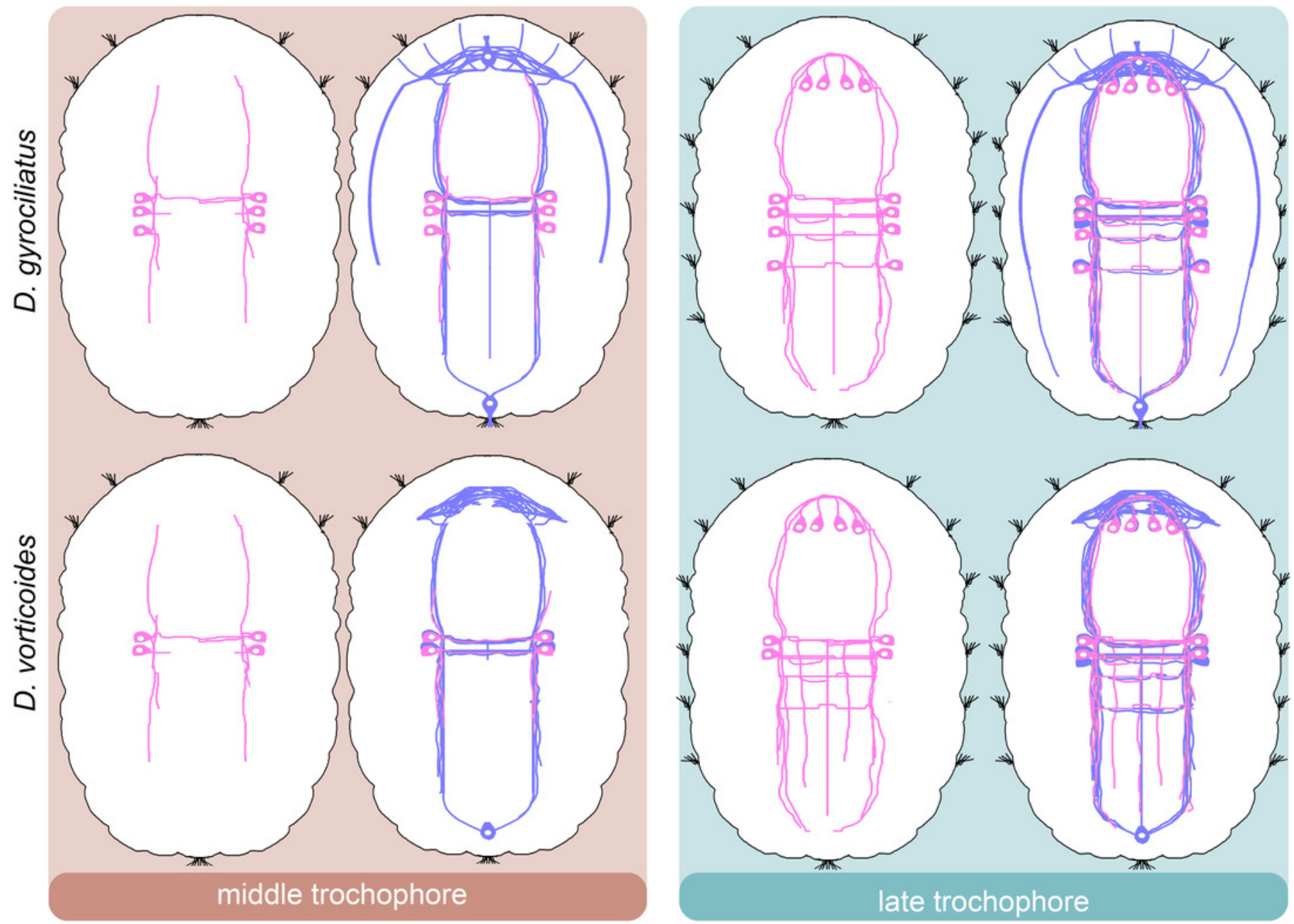
Figure 12

Summary diagram of FMRFa-IR elements in $D$. gyrociliatus and $D$. vorticoides.

The first FMRFa-IR cell appears during the middle trochophore stage in $D$. gyrociliatus; it is the early anterior cell that expresses FMRFa-IR. In D. vorticoides, two first FMRFa-IR cells appear anteriorly above the neuropile during the late trochophore stage. The apical end is up. Relative dimensions are not to scale. Blue- tubulin; salmon- FMRFa.
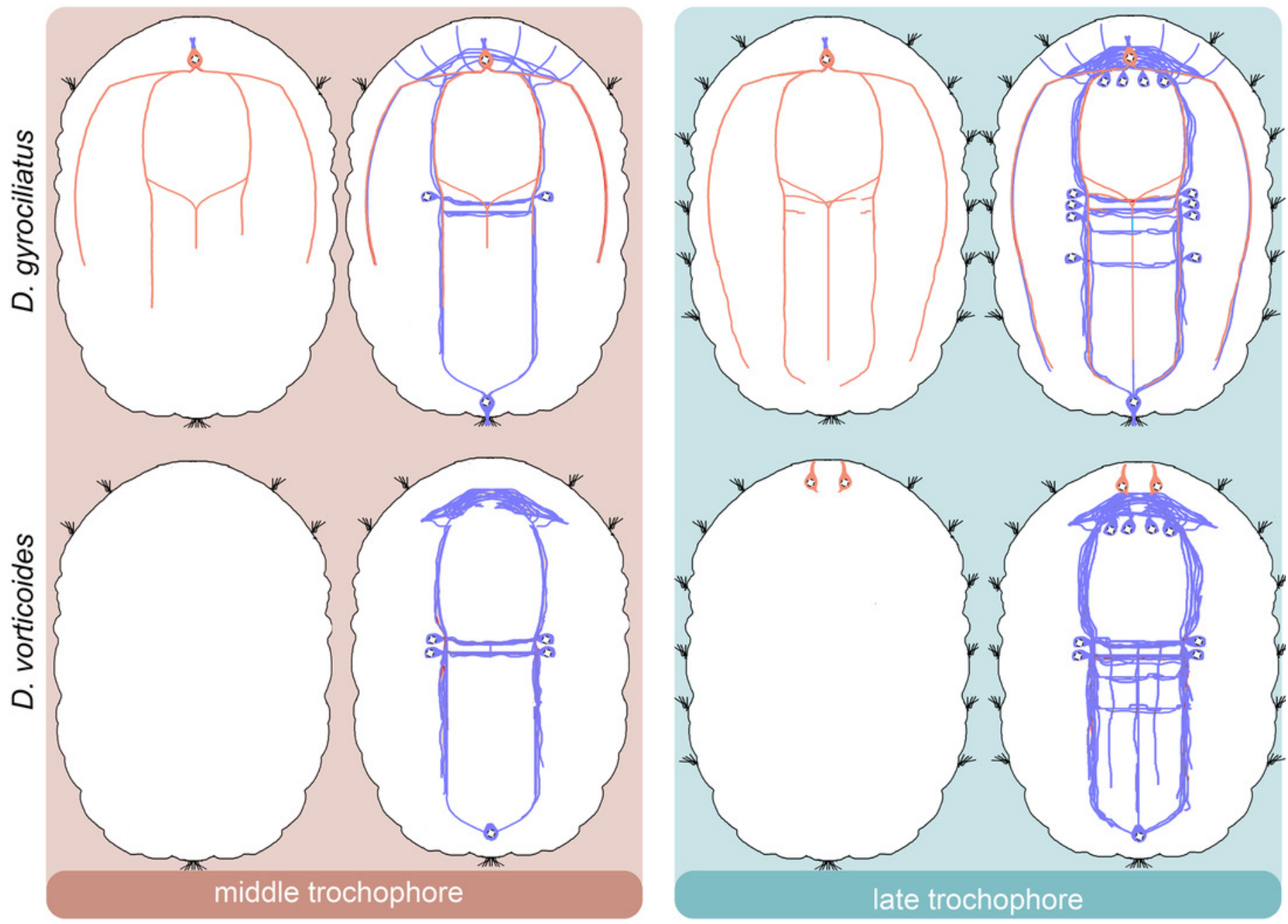


\section{Figure 13}

Summary diagram of the neurogenesis in $D$. gyrociliatus and $D$. vorticoides.

The first anterior cell in $D$. gyrociliatus and anterior and posterior cells in $D$. vorticoides appear during the early trochophore stage. They do not have 5-HT-IR or FMRFa- IR. In D. gyrociliatus, the first 5HT-IR cells appear at the first commissure level, and the anterior cell becomes FMRFa-IR at the middle trochophore stage. In D. vorticoides, 5-HT-IR cells appear at the middle trochophore stage, while FMRFa-IR appears during the late trochophore stage. At the late trochophore stage, more 5-HT-IR and FMRFa- IR cells and processes appear in both $D$. gyrociliatus and $D$. vorticoides. Still, they represent only a tiny fraction of the whole nervous system. The apical end is up. Relative dimensions are not to scale. Blue- tubulin; pink- 5-HT; salmon- FMRFa. 

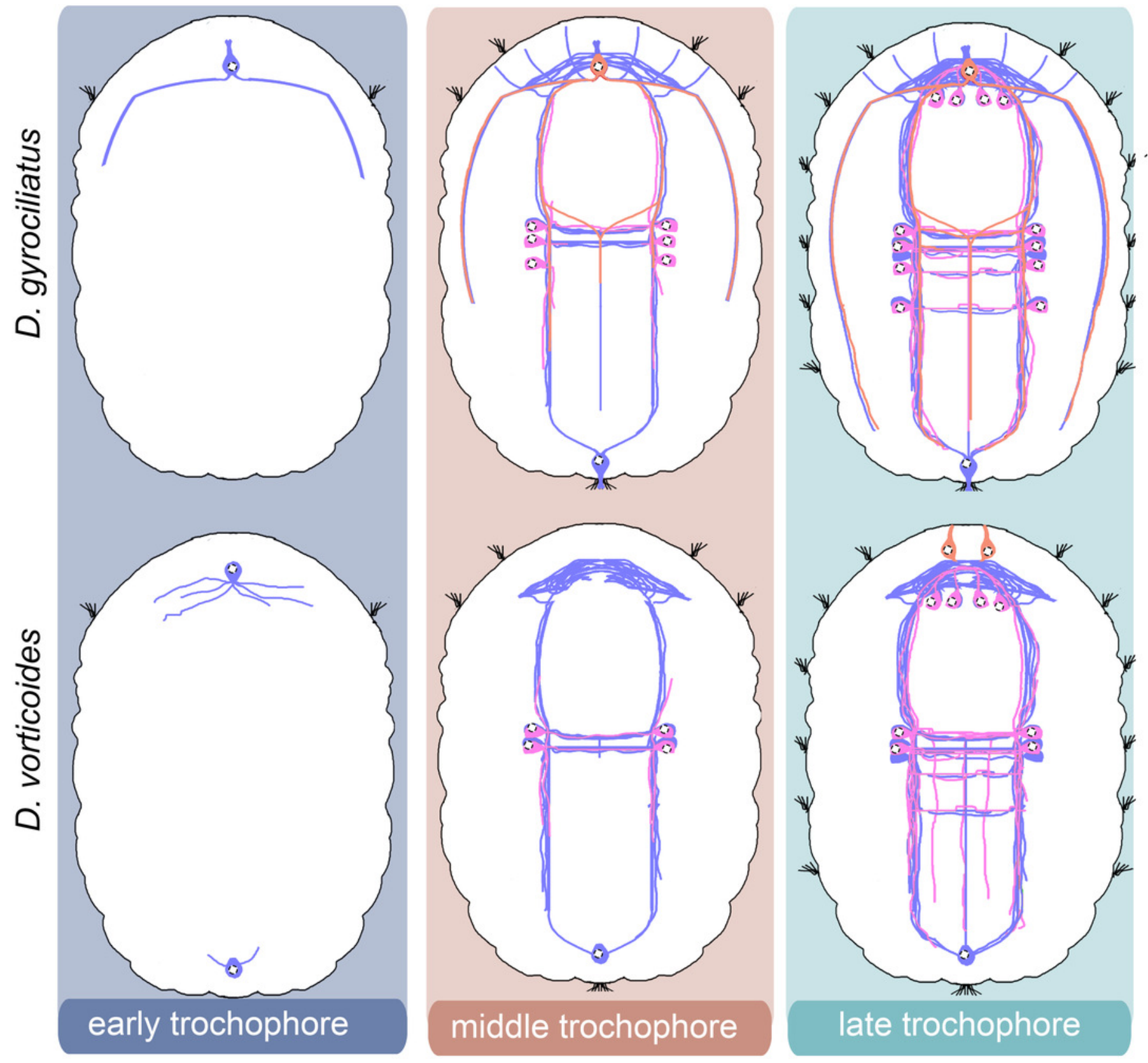

middle trochophore

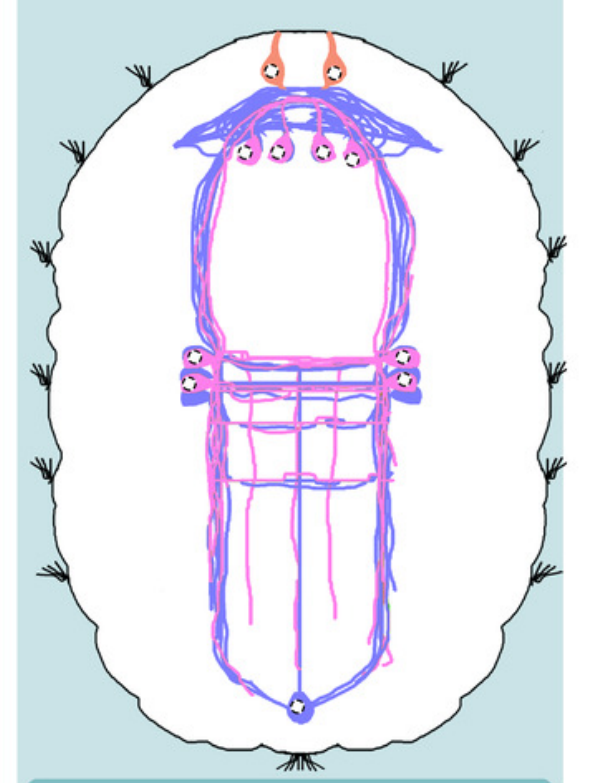

\section{late trochophore}




\section{Figure 14}

Comparative diagram of the early neurogenesis across Annelida.

The diagram is based on the recent data from Sedentaria (Kumar et al., 2020); Errantia (Starunov, Voronezhskaya \& Nezlin, 2017); Dinophiliformia (this study); Sipuncula (CarrilloBaltodano et al., 2019), and Oweniidae (Carrillo-Baltodano et al., 2021). The phylogeny is base on data from ( Martín-Durán et al., 2021). Sedentaria, Errantia, and Dinophiliformia demonstrate the development of the nervous system from the anterior and posterior poles. In Sipuncula and Oweniidae, neurogenesis proceeds from the anterior pole. The apical end is up. Relative dimensions are not to scale. 


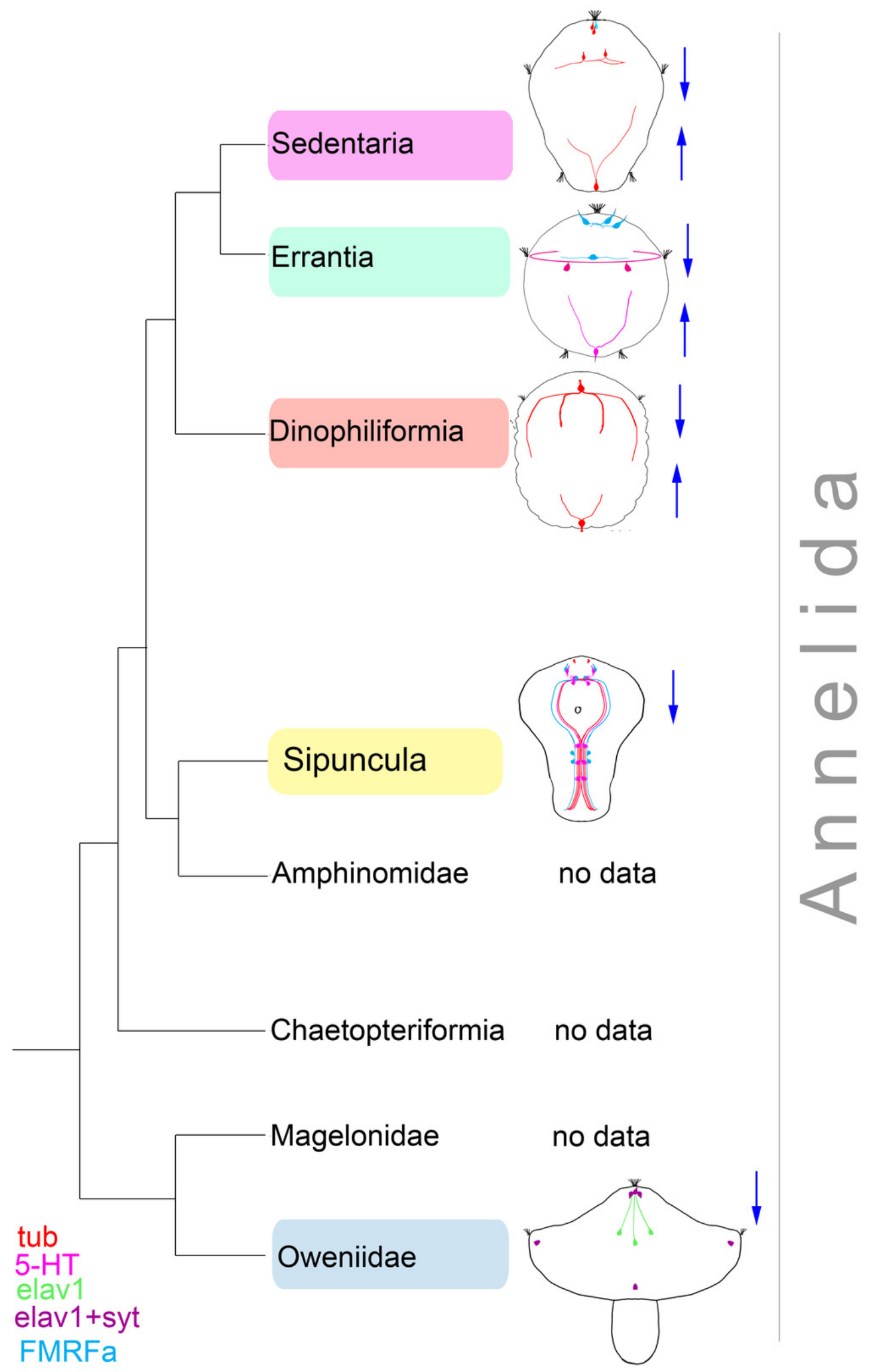

